Alma Mater Studiorum - Università di Bologna DEPARTMENT OF ECONOMICS

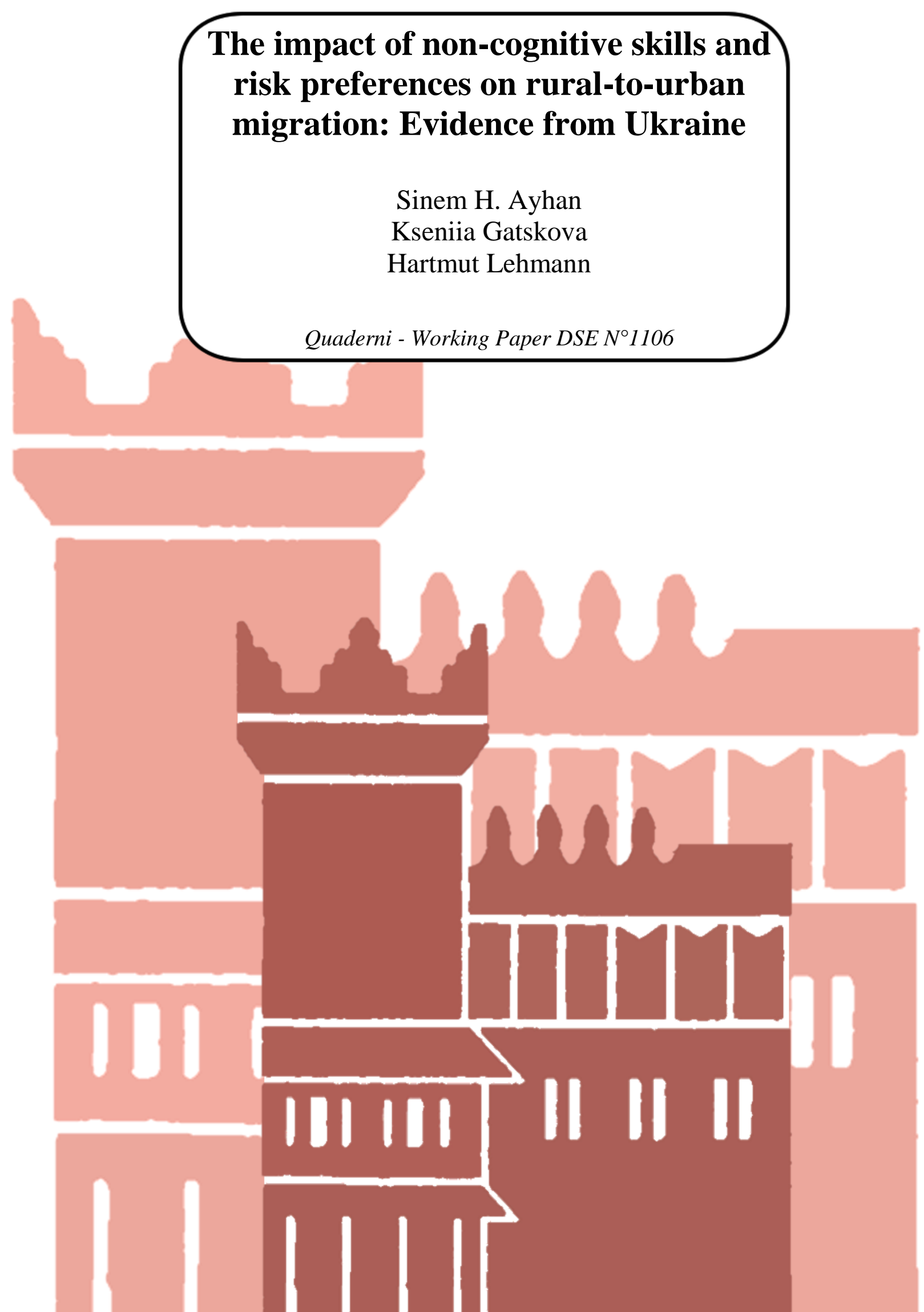




\title{
The impact of non-cognitive skills and risk preferences on rural-to-urban migration: Evidence from Ukraine
}

\author{
Sinem H. Ayhan $(\mathrm{IZA})^{*}$ Kseniia Gatskova $(\mathrm{IOS})^{\dagger}$ \\ Hartmut Lehmann (University of Bologna \& IZA) $\ddagger$
}

September 2017

\begin{abstract}
This paper provides evidence on the impacts of non-cognitive skills and attitudes towards risk on the decision to migrate from rural to urban areas. Our analysis is based on a unique four-wave panel of Ukrainian Longitudinal Monitoring Survey for the period between 2003 and 2012. Adopting the Five Factor Model of personality structure, and using it in the evaluation of non-cognitive skills, our results suggest that such personality traits as openness to new experience and the willingness to take risks increase the probability of migration. On the other hand, the non-cognitive skills conscientiousness and extraversion are found to be negatively associated with the propensity to migrate. The effects are statistically and quantitatively significant, and mainly driven by movements from rural areas into cities. Our results are robust to several sensitivity checks, including tests for reverse causality.
\end{abstract}

JEL classifications: J61, D03, D81, R23.

Keywords: migration, non-cognitive skills, Big Five, risk attitudes.

*Institute of Labor Economics (IZA), Schaumburg-Lippe-Str. 5-9, 53113 Bonn-Germany. Phone: +49228 3894403, Email: ayhan@iza.org

†Institut für Ost- und Südosteuropaforschung (IOS) Landshuter Str. 4, 93047 RegensburgGermany , Phone: +49 941 9435436, Email: gatskova@ios-regensburg.de

${ }_{\ddagger}^{\ddagger}$ Department of Economics University of Bologna, Strada Maggiore 45, 40125 Bologna-Italy, Phone: +39 051 2092631, Email: hartmut.lehmann@unibo.it; Corresponding Author. 


\section{Introduction}

A growing body of economics literature has been investigating the role of non-cognitive skills, often referred to as soft skills or personality traits, in predicting micro-economic behavior. In this literature non-cognitive skills, besides cognitive abilities, are documented as important determinants of labor productivity, wages, occupational choices and job search behavior (see Kautz et al., 2014 for a summary). Conceivably, geographic mobility is among those life outcomes which non-cognitive skills might predict. Yet only little is known about the role of non-cognitive skills for individual migration decisions (Bütikofer and Peri, 2016). The current study contributes to this scarce literature by providing evidence on the impact of non-cognitive skills on the decision to migrate within a country.

Considering migration behavior within a resource allocation framework, people migrate to realize their labor market potentials as far as its benefits outweigh the costs. The costs of migration increase with greater uncertainty about other locations, particularly about the housing market, labor market and education opportunities. In this respect, risk attitudes have a high predicting power in explaining the migration decision as recently documented by Jaeger et al. (2010) and Bauernschuster et al. (2014). In an early study, $\operatorname{Sjaastad}(1962)$ asserts non-monetary costs as a key determinant in migration decision. These costs include the emotional burden of leaving the familiar surrounding behind, building up new social relations, adapting to a new social environment, and so on (Sjaastad, 1962). Following this line of thought, we argue that these so-called 'psychic costs' might be the channel through which non-cognitive skills! 1 predict the migration propensity. Each person evaluates these costs subjectively, and hence the size of the costs depends on the individual's characteristics in handling these costs. Certain non-cognitive skills such as openness to new experience may help people perceive these costs to be lower, while other skills may make people strongly attached

\footnotetext{
${ }^{1}$ One may argue that non-cognitive skills comprise both personality traits and risk preferences. To avoid conceptual confusion, in this text we use the term 'non-cognitive skills' only to indicate personality traits, particularly the Big Five factors.
} 
to their communities and thus perceive the costs of leaving as higher.

Although we moot that the channel through which the relationship between noncognitive skills and the migration probability works is related to the costs or perceived costs of migration, we do not dispute the role of expected returns in the decision to migrate. Of course, persons tend to migrate because they expect higher returns in the destination state for themselves or higher returns for the sending household (Stark, 1991). Whether people expect to get higher returns to their non-cognitive skills in urban centers and whether this expectation supports their motivation to change the place of residence is, however, a contentious issue that we do not want to pursue here. The channel of costs or perceived costs of migration through which some of the non-cognitive skills might impact on the decision to migrate strikes us as much more straightforward. We do not develop a theoretical model that shows the link between non-cognitive skills and rural-to-urban migration; essentially we want to identify those non-cognitive skills that are important predictors of migration in a consistent fashion.

The focus of this study is rural-to-urban migration in Ukraine. Rural-to-urban migration is an especially important type of mobility in the developing country context, since it has the potential to foster economic growth by reallocating workers from economically lagging-behind regions to large urban centers, where returns to human capital are higher. For the empirical analysis, we use the four waves of the Ukrainian Longitudinal Monitoring Survey (ULMS), a panel data set launched in 2003. In addition to rich information on individual and labor market characteristics, the ULMS includes direct measures of attitudes towards risk in the survey years of 2007 and 2012 and a 24-item module on non-cognitive skills added in 2012. Using this skill module we assess non-cognitive skills based on the widely accepted 'Big Five' taxonomy in the personal psychology literature -openness, conscientiousness, extraversion, agreeableness, and neuroticism (Goldberg, 1990; John and Srivastava, 1999; Lang et al., 2011). We propose a mapping of the 24 items into the Big Five taxonomy, utilizing the facets of the Big Five domains characterized by John and Srivastava (1999).

Our results suggest that non-cognitive skills such as openness to new experience 
and willingness to take risks, which help reduce the perceived cost of migration, increase the probability of an individual migrating from rural to urban areas. On the other hand, our estimates show conscientiousness and extraversion to be negatively correlated with the propensity to migrate. The effects are mainly driven by movements from rural areas into cities. The marginal effects from the estimation of a probit model indicate that a one standard deviation increase in openness is associated with a 0.2 percentage point higher probability of moving into cities, controlling for individual characteristics, preferences and regional macro conditions. The effect is larger for conscientiousness, in that individuals who rate themselves as one standard deviation more conscientious have a 0.5 percentage point lower probability of moving into cities. As of risk preferences, the probability of rural-to-city migration is about 0.5 percentage points higher among relatively more risk-loving people. The magnitudes of the impacts are substantial considering the unconditional rural-to-city migration probability of about 1.5 percent. On the other hand, we find no consistent evidence supporting an association of neuroticism with the migration propensity. Agreeableness as well as conscientiousness, on the other hand, are found to lower moves from rural areas to towns. Also, more risk-loving people tend to have a lower likelihood to migrate to towns. These effects are, however, not as consistent as the factors co-determining rural-to-city migration, i.e., openness, conscientiousness, extraversion and an affinity for risk taking.

Our results also indicate that a full model, which uses the Big Five factors and risk preferences jointly, fits the data substantially better than models that use them separately. Moreover, we provide evidence that the estimated effects of personality and risk attitudes are not driven by reverse causality. To the best of our knowledge, this study is the first one that explores simultaneously the effects of the Big Five factors and risk preferences on migration decisions and, in addition, focuses on these effects in a developing country context. Our findings are roughly in line with the findings from the psychology literature that indicate a strong impact of openness and conscientiousness on migration behavior, whilst either very little or no effect of ex- 
traversion. Our results are also consistent with the previous evidence by Jaeger et al. (2010) andBauernschuster et al. (2014), showing that risk loving people are more likely to migrate.

The rest of the paper is organized as follows. In the following section, we provide some background information about demographic developments and migration patterns in Ukraine. Section 3 presents a brief summary of the pertinent literature on the link between non-cognitive skills and life outcomes and embeds our paper into this literature. Section 4 introduces the data, motivates the variables used in the regression analysis, and discusses our research strategy. While Section 5 presents the main estimation results, Section 6 provides some extensions and robustness checks. Finally, Section 7 discusses the results and provides some conclusions.

\section{Demographic developments and internal migration in Ukraine}

In the last three decades, very little research has been done on internal labor mobility in Ukraine and many questions related to its different aspects remain unanswered. Most studies rely on the data coming from official statistics that are often criticized for being not accurate enough since they reflect only registered population moves. To put our paper into context, we provide a brief overview of the major economic and demographic developments and of internal migration trends in Ukraine.

During the independence years Ukraine's population contracted by roughly 9 million people from 51,9 million in 1991 to 42,8 million in 2016 (State Statistics Service of Ukraine ${ }^{2}$. This enormous population drop may jointly be explained by a combination of three major factors: low fertility rates (1.5 children per woman $\left.{ }^{3}\right)$, high mortality levels (deficit of births over deaths reached 158711 persons in 2013) and in-

\footnotetext{
${ }^{2}$ http://www.ukrstat.gov.ua/, retrieved on 25 January 2017.

${ }^{3}$ Fertility rate for 2013 according to the State Statistics Service of Ukraine. The fertility rate is traditionally lower in urban (1.365) than in rural areas (1.825).
} 
ternational out-migration (Danzer and Dietz, 2014). These demographic trends were nurtured by unfavorable economic conditions that led to an overall impoverishment of the population. In the 1990s, the country experienced a period of hyperinflation and an enduring economic recession with real GDP falling by over $60 \%$, resulting in high rates of poverty. Among especially affected population groups were families with children and the less educated as well as the rural population (Brück et al. 2010). Although the situation slightly improved in the period of moderate economic growth in the later years, economic shocks such as the global financial crisis and the Great Recession, which hit Ukraine in 2008-2009, and military conflict with Russia, which started with the Russian annexation of Crimea in 2014, led again to a sharp drop in the welfare of the population. The latter conflict resulted in a large number of internally displaced people..$^{4}$ Problems caused by these internal movements, such as, for instance, the difficult labor market integration of newcomers and their limited access to the housing market, pointed to the multiple institutional shortcomings and obstacles that have greatly discouraged internal mobility in the last three decades in Ukraine. In this period, Ukrainians have encountered a number of barriers to internal mobility including a complicated population registry system, weak formal labor market institutions, underdevelopment of housing and credit markets, non-portability of social benefits and wide-spread skills mismatch ${ }^{5}($ Koettl et al. 2014). As a result, the population of Ukraine is considerably less geographically mobile than one would expect given the high economic disparities across regions and between rural and urban areas.

From a regional perspective, Ukraine is characterized by relatively low incomes in the predominantly agricultural oblasts (regional districts) in the West and higher incomes in the industrialized and more urbanized oblasts in the East (Mykhnenko and

\footnotetext{
${ }^{4}$ According to the Ministry of Social Policy of Ukraine, by August 2016, there were 1.8 million internally displaced people registered in the country.

${ }^{5}$ Lack of appropriate skills in rural areas is one of the factors that hinder internal migration, which otherwise would be an expected response to spatial earnings differentials. Some agriculture-dominated regions employ low-skilled workers that cannot easily become qualified for employment in high-wage industrial sectors in other regions.
} 
Swain, 2010). However, as is typical for post-Soviet countries marked by high levels of centralization, the largest differences in earnings persist between the capital city and the rest of the country. According to official statistics, the capital city of Ukraine, Kyiv, accounted for $22.5 \%$ of total GDP in 2014. This share grew substantially since 1996, when it made up only $7.4 \%$. Not surprisingly, Kyiv is the largest magnet for internal labor migrants in the country. At the same time, scholars acknowledge, that internal migration in Ukraine is not always directed from economically lagging to better developed industrial regions but happens mostly within the same region (from rural to urban areas) or between neighboring regions with similar levels of socioeconomic development (Koettl et al., 2014, Kupets, 2014).

In the light of the numerous barriers to internal mobility it is not surprising that the share of the urban population in Ukraine has been growing only slowly in the last decades: it increased from $66.9 \%$ in 1989 to $69.2 \%$ in 2016 . This process is driven by internal movements of mostly young people from rural areas to the cities in search of better economic opportunities. In general, rural areas in Ukraine provide a much poorer standard of living, worse quality of facilities and infrastructure and fewer opportunities for skills acquisition and employment as compared to large urban centers. Hence, economic disparities between rural and urban settlements encourage many people to engage in one of two popular types of internal mobility: permanent movements from rural areas to larger urban centers or commuting $\rrbracket^{6}$ between the (rural) place of residence and the (urban) location of work.

\section{Our study and the literature on non-cognitive skills and life outcomes}

Economic research analyzing the impact of non-cognitive skills on life outcomes has rapidly expanded since the 2008 special issue of the Journal of Human Resources

\footnotetext{
${ }^{6}$ The total number of commuters reached 2.6 million individuals in 2010 , which amounted to $13.2 \%$ of the total number of employed persons.
} 
edited by Weel (2008). In this special issue, Borghans et al. (2008a) link the evidence from the psychology of personality traits to economics. They focus on several areas where progress has been made but also address a number of issues that need further research. In another study by Borghans et al. (2008b) in the same issue the focus is on the relationship between interpersonal styles (caring and directness) and labor market outcomes. Cunha and Heckman (2008) have contributed to this growing literature through a theoretical model formulating the technology of cognitive and non-cognitive skill formation and the contribution of family investment to this formation in early versus older childhood. They further elaborate the identification and estimation of the technology of skill formation in a follow up study (Cunha et al., 2010). Kautz et al. (2014) present a summary of evidence from the economics literature on the predictive power of non-cognitive skills for a wide range of life outcomes, including educational achievement, labor market outcomes, health, and criminality.

In contrast, much less is known about the impact of non-cognitive skills on migration behavior which constitutes the purpose of the current study. To the best of our knowledge, there is only one economic paper on the impact of non-cognitive skills on the decision to migrate. Bütikofer and Peri (2016) investigate the importance of cognitive and non-cognitive skills on the probability of migrating out of one's region of origin for the male population in Norway. Focusing on two aspects of non-cognitive skills, namely 'adaptability' and 'sociability', they find that adaptability has a particularly strong impact on migration for individuals with low cognitive skills. This finding is interpreted as evidence that adaptability skills reduce the non-monetary costs of migration.

In contrast to the scarce evidence on non-cognitive skills and migration in economic research, it has been relatively extensively studied in the psychology literature. Those studies generally rely on the Big Five factor model. In their study using a sample of Finnish twins, Silventoinen et al. (2008) find extraversion and neuroticism positively correlated with the migration propensity to neighboring Sweden. In another study using Finnish subjects, Jokela et al. (2008) point to sociability as an important deter- 
minant of internal rural-to-urban migration. On the other hand, some evidence from the U.S. suggests that high openness and low agreeableness increase the propensity to migrate within- and between-states, while extraversion can only predict within-state migration (Jokela, 2009). Focusing on two elements of the Big Five, Canache et al. (2013) find only a modest positive influence of openness and extraversion on the intention to emigrate from Latin American countries. While for openness the greatest effect is seen among relatively well-educated respondents, for extraversion it is rather a compensating effect in that low-educated respondents are less likely to intend to emigrate, but the education gap shrinks as extraversion rises. Another study, examining the impact of the Big Five factors on the intention to emigrate and using a Lithuanian student sample, finds no evidence for extraversion to have predictive power. The results of Paulauskaite et al. (2010) suggest conscientiousness and openness the only two traits to be linked with migratory intentions.

Following the psychology literature we rely on a Big Five factor model for the analysis of the impact of non-cognitive skills on rural-to-urban migration. The focus of our study is not limited to this, since we analyze the impact of non-cognitive skills together with the attitudes towards risk on migration behavior. Our study has benefited from Jaeger et al. (2010) who provide direct evidence on risk attitudes and internal migration. Using data from the German Socio-Economic panel they find that individuals who are more willing to take risks are more likely to migrate between labor markets in Germany. Non-monetary costs due to general uncertainty (imperfect information) about other locations are considered to be the channel through which risk attitudes determine intra-country mobility. A more recent study by Bauernschuster et al. (2014) using the same data source focuses on internal migration in order to explore the reason why more educated and risk-friendly persons move more easily over longer distances. Their findings suggest less sensitivity among those people to the cultural costs of migration proxied by linguistic variation within Germany, while costs related to geographical distance do not play a role in explaining the higher mobility of higher educated and risk-loving persons. 
Inspired by Jaeger et al. (2010) we consider the ability to bear the non-monetary costs as the main motive why non-cognitive skills might be important for the migration decision. Apart from the mobility costs due to market imperfections or the time and effort spent to search for and get familiar with a new job, there are other non-monetary considerations involved in migration such as the emotional burden of leaving familiar surroundings, family and friends, and adapting to a different cultural environment. These so-called "psychic" costs might increase the costs of moving perceived by individuals (Sjaastad, 1962; Bauernschuster et al., 2014). Unlike travel costs it is not possible to quantify the magnitude of these costs, which is subject to a subjective evaluation by each person. Assessment of these costs may be quite different even among persons with very similar demographic and socio-economic characteristics. We argue that how individuals perceive these costs might be related to personality characteristics. Here, we pursue the question what types of non-cognitive skills might make individuals perceive a lower (higher) cost and thus generate more (less) willingness to migrate.

As documented by Jaeger et al. (2010) and Bauernschuster et al. (2014), because risk lovers are more able to deal with uncertainties connected to moving to a new place, the obvious expectation would be to find a positive relationship between the willingness to take risk and migration propensity. For non-cognitive skills the relationship is not so self-evident given the ambiguity of the previous evidence from the psychology research. Arguably, we may anticipate that skills that reduce the cost of mobility would increase the probability of migration. For instance, openness to experience is expected to help adapt to a new environment and a different culture, and hence decrease the psychic costs of migration and increase the probability of moving. On the other hand, a skill such as conscientiousness described by the tendency to be organized, responsible, and hard-working as well as by a high valuation of persistence and predictability is expected to be negatively associated with the decision to migrate (John and Srivastava, 1999; Kautz et al., 2014). Moving to another place per se contains unpredictability (uncertainties) and inconsistency as it opens a new episode 
in life. Therefore, conscientious people might perceive moving as relatively costly.

It is not straightforward to anticipate the direction of the relationship for every trait. For extraversion the first effect that comes to mind is to increase the migration propensity, because extraverted people have better communication abilities which would help them easily adapt to a new environment; consequently, they should perceive migration as having a lower (psychic) cost. On the other hand, gregariousness is a typical characteristic of rural societies. It is reasonable to argue that social people feel more attached to their own communities as well as more able to increase their well-being in their villages given that kinship plays a key role in every sphere of life including the professional life. In this respect, for extraverted people it might be more costly to leave their familiar surroundings behind. Consistent with this argument, it is documented in the psychology literature that positive emotionality and high level of activity typically possessed by extraverted people enable them to be better-off in their present places and to be satisfied with their current lives (John and Srivastava, 1999; Jokela, 2009; Paulauskaite et al., 2010). Taken together, these facets of extraversion might counterbalance the stimulating effect of extraversion on the migration decision.

Countervailing effects might also arise for agreeableness and neuroticism. More agreeable individuals can more easily conform to different norms of a new environment so that the cost of adaptation would be lower for them. However, those people are also likely to be pleasant and satisfied with their existing lives and have a stronger emotional attachment to their own communities (Jokela, 2009). The latter facet would make them less willing to leave their current place. Similarly, some facets of neuroticism (emotional instability) such as proneness to anxiety and fear, low self-esteem, and vulnerability to stress are expected to make individuals less able to start over a life in a new place. Meanwhile, some other facets of neuroticism such as pessimism, hostility, and irritability might bring about a lower level of satisfaction with their current jobs, neighborhoods or lives as a whole, which would instigate the decision to migrate (Jokela, 2009). Our regression analysis sheds light on the facets of the Big Five factors that dominate in our data regarding the decision to migrate. 


\section{Data, descriptives and empirical strategy}

\subsection{Data}

For the estimation of the impacts of non-cognitive skills and risk preferences on the rural-to-urban migration decision we make use of panel data from the Ukrainian Longitudinal Monitoring Survey (ULMS). As already mentioned, the panel survey launched in 2003 was also carried out in 2004, 2007 and 2012. The ULMS is the only panel data set for Ukraine, which is accessible to researchers worldwide and is representative at the national level (see Lehmann et al., 2012). The ULMS surveys individuals between the age of 15 and 72, who make up our sample. The survey instrument contains an individual questionnaire soliciting information on socio-demographic and labor force characteristics, labor market status, skills, preferences and attitudes, as well as a household questionnaire on the structure of the household, housing conditions, income, assets and expenditures. It is arguably the richest panel data set regarding labor market issues in the transition region.

For the outcome variable of interest, namely rural-to-urban migration, we exploit the survey question related to the "type of settlement of the current place of residence" which is asked in all four waves of the panel survey. Possible answer categories include six types of settlement: village, rural-type settlement, small town (population up to 20 thousands), medium town (population of 20-99 thousands), city (population of 100-499 thousands) and large city (population more than 500 thousands). While we consider villages and rural-type settlements as belonging to a 'rural' area, towns (small- and medium-size) and cities (medium- and large-size) are categorized as 'urban' areas. The dependent variable thus comprises a binary indicator which takes a value of 1 if the respondent changes the type of settlement from a rural area to an urban area between two survey periods and a value of 0 if the respondent resides in a rural area both in the current and last survey period.7

\footnotetext{
${ }^{7} \mathrm{~A}$ potential concern is measurement error in the dependent variable due to 'round-tripping'. Given that there are up to 5-year brackets between two survey periods, it is possible to experience multiple movements within such a relatively long period. Therefore, our dependent variable could
} 
One important feature of the ULMS is its collection of information on non-cognitive skills in the latest wave of 2012, where a set of questions regarding non-cognitive skills was added to the survey. The questions, based on the World Bank's 24-item STEP survey questions regarding non-cognitive skills (Pierre et al., 2014), asks respondents how they perceive themselves. Respondents are asked, for instance, whether they are talkative, are interested in learning new things, tend to worry, and so on. Responses are ranked on a 4-point scale: "1 Almost always", "2 Most of the time", "3 Some of the time" and "4 Almost never". We transform the ranking in a way that a higher ranking refers to a higher value for the corresponding characteristic $(1=$ Almost never $-4=$ Almost always). In the assessment of non-cognitive skills, we map these 24 items into the Big Five factors model, with openness, conscientiousness, extraversion, agreeableness, and neuroticism as the five personality constructs. The Big Five personality factors represent a widely accepted, comprehensive, and ample frame for delineating the structure of core personality traits over adulthood (Lang et al., 2011: 550). Given its universal structure validated by numerous empirical studies from different cultures as well as its rank order stability over the life cycle, we prefer the Big Five Factor model to the usage of single traits such as self-efficacy or self-esteem, which show less rank order stability (Goldberg, 1990; John and Srivastava, 1999; Lang et al., 2011).

Our mapping into the Big Five factor model largely benefits from the domains characterized by John and Srivastava (1999) and Kautz et al. (2014). Table 1 presents the original table of the 24 items and the corresponding Big Five factors into which these items are mapped. While generating the Big Five constructs, the scale of some items -those denoted by '*'- are reversed for the sake of coherence with the defining construct. Each of the Big Five factor is the simple average of the corresponding items and the averages are standardized with a mean of zero and standard deviation of 1 . Because the information on non-cognitive skills is only available in the survey year of 2012, we treat the Big Five personality constructs as fixed over the sample period.

underestimate the rural-to-urban migration if movers migrate back to the rural area between two survey periods. A preliminary check performed by us, which employs information on moves between reference weeks, indicates that 'round-tripping' is negligible. 
Whether this assumption is plausible is taken up in the robustness section of the paper. It is also worthy of note that the treatment of the non-cognitive skills fixed over the period requires us to use a balanced panel straddling the years 2003 to 2012. 8

The ULMS also introduced a module on risk preferences in 2007 and 2012, identical to the module in the German Socio-Economic Panel (SOEP). Respondents are asked about their willingness to take risks in general and in life-specific domains.9 In our empirical analysis we only use the general risk measure. The general risk question asks: "How do you see yourself: are you generally a person who is willing to take risks or do you try to avoid taking risks?" The answer can be on an 11-point scale, from 0 "completely unwilling to take risks" to 10 "completely willing to take risks". In our main regressions we rely on a dichotomous variable, the risk preference indicator, which takes the value of 1 if the respondent chooses a value of 6 or higher on the 0 -to10-scale. This mitigates potential problems from different use of scales, as explained by Jaeger et al. (2010). ${ }^{10}$

Similar to the Big Five measures, we treat preferences as (partly) fixed over the sample period. In particular, we assign the values of risk preferences measured in 2007 to the previous survey years of 2003 and 2004. Whether this choice implies that we have a reverse causality issue will be analyzed in section 6 .

\subsection{Descriptive statistics}

Table 2 presents summary statistics of the variables used in the regression analysis for rural-to-urban movers, rural stayers, and the urban sample. The former two compose our analysis sample. As the 2012 survey is the only year with complete information on both non-cognitive skills and preferences, the statistics reported in Table 2 are for 2012.

\footnotetext{
${ }^{8}$ We did not pursue exploratory factor analysis since the cited literature provides us with a very intuitive and clear guidance regarding the mapping of the 24 items into the Big Five factors. Furthermore, exploratory factor analysis is particularly useful when researchers have only vague notions of how to project high-dimensional data onto a lower dimensional space, which is not the case here.

${ }^{9}$ These life-specific domains are: financial matters, career matters, health matters, sports and leisure, as well as car driving.

${ }^{10}$ The risk index, which measures risk attitudes on the 11-point scale is only used for some robustness checks.
} 
However, we also present summary statistics of other years for the available variables in Table A.1 in the appendix. Table 2 shows those rural-to-urban movers who moved between 2007 and 2012, the period encompassing the Great Recession. If we compare this table with Table A.1, we see that between 2007 and 2012 the number of moves was particularly small compared to the period between 2003 and 2004. This lower number could be related to less mobility in times of economic crisis but it could also point to the problem of 'round-tripping'. While we are not able to really disentangle these two potential causes our preliminary check of 'round-tripping' mentioned in footnote 7 makes us, however, lean towards the first explanation. A third, and maybe most convincing reason for this drop in numbers could be a selection issue. Nearly all the rural-to-urban movers whom we observe are part of the original sample that was surveyed in 2003. It is certainly feasible that those with the largest propensity to move to an urban environment moved early in the reported period and once we arrive in 2007 the pool of those willing to move has nearly been depleted. Whilst the data at hand do not allow us to make a distinction between this explanation of the falling moves over time and the previously mentioned reasons, this third potential explanation will strongly influence our research strategy that we discuss below.

The urban sample is composed of those who were born and currently reside in urban areas as well as those who moved into urban areas. Table 2 demonstrates that the urban sample is significantly younger than the rural sample. Furthermore, about $70 \%$ of the urban sample prefer to communicate in Russian; these respondents are likely to be concentrated in the center and east of the country. In line with expectations, the education level and employment rate among the urban sample is higher than among rural stayers. Consistent with these patterns, compared to rural stayers, the movers into urban areas are much younger, relatively more educated, more likely to be married but have less children, more likely to be employed and less likely to prefer Ukrainian for communication.

Table 2 also shows the average values of the Big Five factors (on a 4-point scale) separately for movers and stayers. We see a positive and statistically significant differ- 
ence in the average value of openness and agreeableness for movers relative to stayers. As for conscientiousness and neuroticism movers score, on average, lower than stayers. The negative difference for each of these two skills is also statistically significant. However, as far as extraversion is concerned, the difference between movers and stayers is not statistically significant. Next, we present how attitudes towards risk are distributed between rural-to-urban movers versus stayers. As shown in Table 2, 23\% of movers score their risk attitudes 6 or higher on an 11-point scale, which is about 5 percentage points higher than rural stayers. Risk preferences are relatively lower scored among movers compared to stayers in 2007. The difference between the two survey years are mainly driven by movers who scored significantly lower in 2007 than 2012. The difference is more apparent for the index measure, thus we rely in our analysis on the dichotomous indicator variables as they can better mitigate the potential measurement error problem. A relevant concern can also be reverse causality, in that the migration experience might have led to an increase in the willingness to take risks or might have prompted respondents to reveal themselves as more risk loving. We discuss this potential endogeneity problem due to reverse causality in section 6 where we perform robustness checks of our estimation results that address this issue.

As a final descriptive exercise, we examine the distribution of the responses to the general risk questions for the rural and urban samples in 2007 and 2012. As shown in Figure 1, the average of the risk index is higher in the urban than in the rural sample in both survey years. While the largest difference between the rural and urban is among the most risk-averse group in 2007, we do not see such a remarkable difference in 2012. More specifically, in 2007 one out of four rural residents are completely unwilling to take risk in general, whereas about $18 \%$ of the urban residents are represented in this group. 


\subsection{Empirical strategy}

To investigate the impact of non-cognitive skills and risk preferences on the probability of migration, we estimate the following basic specification of a probit model:

$$
Y_{i, t}=\alpha+N_{i}^{\prime} \beta+\gamma P_{i, t+\tau}+X_{i, t-1}^{\prime} \delta+\epsilon_{i, t}
$$

where $\tau=\{0,1,2\}$.

$Y_{i, t}$ indicates a dummy variable which takes the value of 1 if the respondent $i$ resides in the urban area during the reference week of survey period $t$, but was residing in a rural area during the reference week of the previous survey period, at time $t-1$. It takes the value of 0 if the respondent's current and last settlements are both in the rural area. $N_{i}$ is a vector of non-cognitive skills represented by the Big Five which are standardized to have a mean of 0 and standard deviation equal to 1 . Because we observe responses to non-cognitive skill questions only in 2012, we assume them as time-invariant characteristics of the individual. In section 6 we perform a robustness check which shows that this is a reasonable assumption. The variable $P_{i, t+\tau}$ is the risk indicator which takes the value of 1 for values greater than 5 (on a scale of 0 to 10). The risk measure is observed in 2007 and 2012 surveys. For the most part, we assign the values of risk preferences measured in 2007 to the previous survey years of 2003 and 2004. However, when the risk measure is not available in 2007 we use the risk measure of 2012. In the most extant basic specification, $X_{i, t-1}$ is a vector of individual characteristics with dummy variables for female, married, employed, educational attainment and Ukrainian as the preferred language of the interview, as well as continuous variables including age, age squared, the number of children in the household and the log of household income. For the time-varying covariates we rely on information from the previous survey year in order to rule out reverse causality problem, i.e., the covariates are measured at time $t-1$, before migration happens. Finally, $\epsilon_{i, t}$ is a white noise error term.

The estimated coefficients of $\beta$ capture the impact of non-cognitive skills on the 
propensity to move from rural to urban areas, holding risk attitudes and other individual characteristics constant. A concern would be that measurements of non-cognitive skills might be correlated with risk preferences, and this could yield biased coefficient estimates on the non-cognitive skills covariates. For instance, if those who have a higher score of conscientiousness are more risk averse, then the impact of conscientiousness might be overestimated by controlling for risk attitudes. We therefore use non-cognitive skills and risk preferences separately as well as together in specifications in order to see whether this potential bias exists (Bütikofer and Peri, 2016:16).

As we discussed in the previous descriptive section, most of the moves from rural to urban locations occurred before 2007, i.e., before the respondents provided selfassessed measures on risk preferences. One research strategy might consist in limiting our analysis to the period 2007-2012; this way we could condition on risk measures provided in 2007 that were solicited before any rural-to-urban move occurred. However, with this strategy we would ignore most of the moves that we can observe in the data set, missing all those movers who might have had a particularly high propensity to change their residence from rural to urban. We, therefore, rely on an empirical model that uses the risk measure as an explanatory variable even if migration occurred before respondents were asked about their risk preferences. As this raises reverse causality issues, we perform several reverse causality tests and also report the results when the analysis is restricted to migration episodes between 2007 and 2012. Since these latter results are qualitatively similar to the results when all moves are considered and since the reverse causality tests do not point to reverse causality we are confident that our research strategy that uses the fullest information available is the most appropriate one.

\section{Main results}

Table 3 presents marginal effects of a probit model that estimates the probability to migrate from rural to urban areas. Because of substantial differences in the insti- 
tutional and economic structures of cities and towns -although we classify both as urban-, the decision to move into a city may require distinctive personality characteristics than moving into a town. Therefore, we break down results by rural-to-city and rural-to-town migration, presented in Table 3 in columns (4)-(6) and columns (7)-(9), respectively. Table 3 displays results for different sets of control variables. While in columns (1), (4) and (7) we do not control for any demographic and socioeconomic characteristics but only the Big Five, columns (2), (5) and (8) also include pre-determined (demographic) characteristics such as gender, age, age squared and Ukrainian language ${ }^{11}$ as covariates, and columns (3), (6) and (9) additionally include socio-economic controls that may be jointly determined with the migration decision, including marital status, number of children, type of educational attainment and employment status.

In all nine specifications we find statistically significant evidence that conscientiousness is negatively related to rural-to-urban migration. For instance, in column (2) where we only control for the pre-determined characteristics, we estimate that one standard deviation increase in conscientiousness is associated with a 0.8 percentage point lower probability of moving from rural to urban areas. Breaking the results down, this corresponds to a 0.5 - and 0.2 - percentage point lower probability of rural-to-city migration and rural-to-town migration, respectively (columns 5 and 8). The estimated effects are substantial given the unconditional migration probability of 3 percent from rural to urban areas, which is evenly split between rural-to-city and rural-to-town moves. We also find that individuals who rate themselves as (one standard deviation) more open to new experiences have a 0.3 percentage point higher probability of moving from rural to urban locations. A similar coefficient size of agreeableness, however, is linked to a 0.5 percentage point decrease in the probability of moving into an urban area. The effect of agreeableness on rural-to-urban migration is mostly attributable

\footnotetext{
${ }^{11}$ We consider the pre-determined characteristics exogenous, bearing in mind that the language may determine an individual's initial place of residence. On the other hand, we take language chosen for the interview as a good proxy of ethnicity, a characteristic certainly exogenous to the migration decision.
} 
to the decision to moving into towns. We also find a negative impact of extraversion on the migration behavior, which is salient only for rural-to-city migration. Finally, neuroticism is found to be uncorrelated with any type of migration.

As for demographic and socio-economic characteristics, the inclusion of them as control variables substantially reduces the size of the marginal effects of personality traits. For some traits, such as openness, the effect remains statistically significant only for rural-to-city migration when both demographic and socio-economic characteristics are included in the model. On the other hand, the signs of the marginal effects of the controls are generally in line with migration theory. Older individuals are less likely to migrate and the effect has the expected concave shape. Net household income, education level and the Ukrainian language are the variables which have the highest and most consistent explanatory power. The probability of rural-to-urban migration is approximately 3 percentage point lower among those who prefer to communicate in Ukrainian rather than Russian. As for moving into cities or towns, the effect is smaller, yet strongly significant. The probability of migration increases with the education level, and it is the highest among university graduates. The impact of household income is also positive: members of financially better-off families are more likely, arguably more able, to migrate into cities. On the other hand, gender, marital status, having a child and the employment status do not predict the migration propensity.

Table 4 extends the model by including the risk preference measure as a covariate. The inclusion of the risk variable in the analysis does not bring about a substantial change in the impact of personality traits as a comparison of Table 3 and Table 4 shows. This suggests that the Big Five traits, and risk preferences represent distinctive features of personality and that they operate as complements when explaining the propensity to migrate.

In line with the previous literature, we find that individuals who are relatively more willing to take risks are more likely to migrate. This effect is however present only for rural-to-city migration. The probability of moving into cities is a third of a percentage point higher for relatively more risk-loving people, controlling for demographic and 
socio-economic characteristics. In contrast, we find a strong negative association between risk willingness and rural-to-town migration. This might be an indication that the push and pull factors regarding rural-to-town migration are very different from the push and pull determinants of moves from rural to city locations.

Search models predict that mobility across jobs and across space falls when local macroeconomic and labor market conditions become more adverse (Pissarides, 1994). We, therefore, include the unemployment rate or the log of GDP both at the oblast level in Table 5, in order to control for local macroeconomic or labor market conditions 12 . Table 5 presents the impact of the Big Five together with risk preferences when we add either the local unemployment rate or the local GDP growth rate. A comparison with Table 4 makes it clear that the inclusion of either of the macro indicators does not change the coefficient estimates on non-cognitive skills and risk preferences. This suggests that regional controls are orthogonal to the Big Five and risk preferences and that these preferences and a subset of the Big Five, namely openness, conscientiousness and extraversion consistently predict internal migration from rural areas to cities. When it comes to rural-to-town migration, we see a consistently estimated negative impact of conscientiousness and agreeableness as well as of risk preferences. Table 5 also demonstrates that internal migration is pro-cyclical since adverse local labor market and macroeconomic conditions lower spacial mobility: the regional unemployment rate is negatively and local GDP growth positively related to the decision to migrate. It is also noteworthy that macroeconomic and local labor market conditions affect rural-to-city and rural-to-town migration in equal measure and in the same direction. This last result confirms that workers tend to stay put when macroeconomic and labor market conditions get worse and that this heightened reluctance to move is independent of the potential destination.

We furthermore investigate whether non-cognitive skills and risk preferences con-

\footnotetext{
${ }^{12}$ There are 24 Oblasts in Ukraine, forming the largest administrative units. Oblasts are larger than, e.g., counties in the U.S. but smaller than, e.g., lands in Germany. The macroeconomic measures introduced in Table 5 are hence only rough proxies for local macroeconomic and labor market conditions. Since most migration, however, takes place within oblasts, we can suppose that internal migration is pro-cyclically related to macroeconomic measures at the oblast level in Ukraine.
} 
tribute jointly to the explanation of the migration behavior by calculating the Akaike's information criterion (AIC), one goodness-of-fit measure applied to non-linear models. Given two models are estimated with the same data, the model with the smaller value of the information criterion is considered to show a better fit 13 . Each row in Table 6 shows, besides the pre-determined characteristics (i.e., age, age squared, gender and language), which of the two sets of regressors -Big Five measures, risk measures- are separately or together included in the regression analysis. Inspection of Table 6 shows that the Big Five factors have larger explanatory power, improving the goodness-of-fit measures more than the risk factor. Consistent with this finding, as shown in appendix Table A.2, the adjusted R-squares obtained from the OLS estimation are larger in models where the Big Five factors are included compared to the models controlling only for the risk measure. As for rural-to-city migration, where risk is consistently estimated as a significant positive determinant of the migration probability, the explanatory power is maximized, i.e., the AIC is smallest, when both non-cognitive skills and risk attitudes are included in the regression. This finding is consistent with the evidence by Becker et al. (2012) who show very low correlations between the Big Five and risk preferences and their complementarity in explaining life outcomes in Germany. However, differently from the labor market outcomes explored by Becker et al. (2012), our data hardly suggest a strong complementarity between the Big Five and risk preferences in explaining rural-to-urban migration in Ukraine.

\section{Extensions and robustness checks}

A potential concern is that most of the moves observed in the data occur before risk preferences were first measured in the 2007 wave and that our results might possibly be subject to a reverse causality problem. As stated by Jaeger et al. (2010), successful migration could make individuals apt to rate themselves as more risk loving, which

\footnotetext{
${ }^{13}$ The AIC is a measure for comparing non-linear models that are estimated with maximum likelihood. AIC is defined as:

AIC $=-2 * \ln ($ likelihood $)+2 * k$, where $\mathrm{k}=$ number of parameters estimated.
} 
would yield an upward bias in the risk estimates from the regression of rural-to-city migration. To check the relevance of this concern, we first estimate models similar to those of Table 4, restricting the dependent variable to represent moves between 2007 and 2012, i.e., after risk attitudes were measured in 2007. This way we clearly avoid any reverse causality issue. Given that the number of moves is very limited over the period 2007 to 2012, the results of Table 7 are encouraging . They show similar point estimates and statistical significance as in Table 4 regarding rural-to-city migration, as long as we only condition on the pre-determined covariates. For all specifications with respect to rural-to-town migration and when we condition on both sets of covariates in all specifications there is too little variation in the data to get meaningful results.

As a second and more direct check of reverse causality, exploiting the panel feature of the ULMS, we construct a variable representing the change in the risk index between 2007 and 2012. This change in the risk measure is regressed on a migration dummy (for moves between 2007 and 2012). Similarly, in a separate regression, we use as the dependent variable the risk index in 2012, and investigate the impact of internal migration (between 2007 and 2012), conditioning on the risk index measured in 2007 -before the move occurred. The results are provided in Table 8 . The statistically insignificant coefficient estimates in the table reveal that internal migration between 2007 and 2012 do neither affect the observed change in the risk index over the period nor the level of risk attitudes in 2012 once we control for the risk index in 2007. We therefore conclude that reverse causality does not bias our results concerning the impact of risk attitudes on migration. This evidence is in line with the results of earlier works of Gibson et al. (2016) and Jaeger et al. (2010), who also found no impact of migration on risk preferences.

We also assume stability of the Big Five personality traits over the panel period. Reverse causality could also be a concern for these skills, despite the sound evidence in the personal psychology literature regarding rank order stability over time and relatively little malleability of these skills after adolescence (Lang et al., 2011). We cannot internally check the validity of our assumption given the lack of repeated information 
on personality traits in the ULMS, in contrast to the risk measure. We, therefore, implement a different approach to validate our results following Groves (2005) and Heineck and Anger (2010). We predict residuals from the regressions of the Big Five factors on age and age squared and estimate the impact of these predicted residuals on the migration behavior. The idea behind this approach is to net out the age effect of non-cognitive skills, so that the estimated impact is a time-invariant (age-free) component of personality. Table 9 shows very similar results to our basic specifications in Table 3. So, after we have 'de-aged' our measures of non-cognitive skills, openness, conscientiousness and extraversion remain important predictors of rural-to-city migration, while conscientiousness and agreeableness significantly affect rural-to-town migration in all three specifications like in Table 9. Hence, our initial assumption of the time-invariance of the Big Five factors taken from the psychology literature, seems to hold with our data.

Finally, it is worth mentioning that attrition is not a concern in our paper. If the reason an individual leaves the sample is correlated with the idiosyncratic error term -those unobserved factors that change over time and affect the outcome variablethen the resulting selection problem can cause biased estimators. However, since we use a balanced panel (given the operational sample focuses on those observed in 2012) the problem we might face is not an attrition problem, but rather non-random subsample selection due to the usage of a balanced panel (i.e., unobserved characteristics associated with retention may be correlated with the unobserved characteristics of the migration outcome). The focus of the study is the evaluation of the impact of noncognitive skills on migration. Since these skills are only measured in 2012, the analysis must rely on a balanced panel as indicated before.

\section{Discussion and conclusions}

Using the rich panel data set of the Ukrainian Longitudinal Monitoring Survey we analyze the link between non-cognitive skills and risk preferences and rural-to-urban 
migration in Ukraine. To this purpose we map 24 facets of non-cognitive skills into the Big Five personality traits, i.e., openness to new experiences, conscientiousness, extraversion, agreeableness and neuroticism. We estimate probit models with the Big Five personality traits as covariates and investigate whether some of these traits have predictive power. We also analyze the importance of attitudes towards risk in general for internal migration behavior. We also check whether using non-cognitive skills and risk attitudes jointly gives us more predictive power in the estimation of the probability to migrate.

Our results show that three of the Big Five, namely openness to new experiences, conscientiousness and extraversion, as well as attitudes towards risk in general are consistently correlated with rural-to-urban migration. These results are driven by rural-to-city migration. Moving from a rural area to a town is also correlated with conscientiousness, agreeableness and the willingness to take risk, but these correlations that are all negative are not as consistently estimated as the above mentioned predictors of rural-to-city migration. We, therefore, limit our discussion to the drivers of rural-to-city migration.

The estimated effect of a one standard deviation increase in a personality trait that has some predictive power changes the probability of moving from a rural area to a city by between 0.3 and 0.5 percentage points. The size of the effects are substantial in that the unconditional rural-to-city migration probability amounts to 1.5 percent. The notion that non-cognitive skills might work through the channel of psychic costs of migration seems to be borne out by our results. We find a consistent positive correlation between openness to new experiences and the probability to migrate to cities; persons endowed more with this personality trait are better able to adapt to a new environment and a different culture. Conscientiousness is, on the other hand, consistently negatively correlated with the likelihood of rural-to-city migration. Persons with this trait are hard-working, responsible and well-functioning in the environment where they find themselves, hence they have little reason to be dissatisfied with their current situation. Doing well in the given environment in combination with a dislike 
for unpredictability might explain why conscientious people perceive out-migration as relatively costly. That extraverted people tend to see out-migration as relatively costly seems to indicate that those facets of this personality trait that keep individuals tied to their place of origin are stronger than the facets that enable them to deal with new environments relatively well.

Reverse causality tests allow us to conclude that we can interpret our results as being causal as far as risk attitudes are concerned, i.e., risk preferences are determinants of internal migration in Ukraine, whilst internal migration does not seem to influence these preferences. We also perform a robustness check for non-cognitive skills that demonstrates that the assumption of the time-invariant nature of these skills is reasonable. We also show that personality traits and risk preferences are complementary in explaining rural-to-urban migration. This tells us that cross section or pooled data regressions that do not include personality traits when estimating the impact of risk attitudes on life outcomes might suffer from an omitted variables bias. In the final analysis it is at any rate striking that non-cognitive skills are very consistent predictors of rural-to-city migration.

\section{Acknowledgement}

We would like to thank Holger Bonin, Thomas Dohmen, Benjamin Elsner, Robert Grundke, Olga Kupets, David McKenzie, Chiara Monfardini, Mark Schaffer and Anzelika Zaiceva for helpful comments and suggestions. We also thank seminar participants of IZA, of the University of Bologna, IOS-Regensburg, the University of Münster and participants of the EACES Conference in Regensburg in 2016, the Applied Economics Conference 2017, the International Panel Data Conference 2017, and the 2017 ASSA meetings in Chicago. The paper was finalized when Sinem Ayhan and Hartmut Lehmann visited the IOS in Regensburg. 


\section{References}

Bauernschuster, S., O. Falck, S. Heblich, J. Suedekum, and A. Lameli. Why are educated and risk-loving persons more mobile across regions? Journal of Economic Behavior \& Organization, 98:56-69, 2014.

Becker, A., T. Deckers, T. J. Dohmen, A. Falk, and F. Kosse. The relationship between economic preferences and psychological personality measures. Annual Review of Economics, 4(4):453-478, 2012.

Borghans, L., A. L. Duckworth, J. J. Heckman, and B. Ter Weel. The economics and psychology of personality traits. Journal of human Resources, 43(4):972-1059, 2008a.

Borghans, L., B. Ter Weel, and B. A. Weinberg. Interpersonal styles and labor market outcomes. Journal of Human Resources, 43(4):815-858, 2008b.

Brück, T., A. M. Danzer, A. Muravyev, and N. Weisshaar. Poverty during transition: Household survey evidence from Ukraine. Journal of Comparative Economics, 38 (2):123-145, 2010.

Bütikofer, A. and G. Peri. The Role of Cognitive and Noncognitive Skills in Selecting into Migration. 2016.

Canache, D., M. Hayes, J. J. Mondak, and S. C. Wals. Openness, extraversion and the intention to emigrate. Journal of Research in Personality, 47(4):351-355, 2013.

Cunha, F. and J. J. Heckman. Formulating, identifying and estimating the technology of cognitive and noncognitive skill formation. Journal of human resources, 43(4): 738-782, 2008.

Cunha, F., J. J. Heckman, and S. M. Schennach. Estimating the technology of cognitive and noncognitive skill formation. Econometrica, 78(3):883-931, 2010.

Danzer, A. M. and B. Dietz. Labour migration from eastern Europe and the EU's quest for talents. JCMS: Journal of Common Market Studies, 52(2):183-199, 2014.

Gibson, J., D. McKenzie, H. Rohorua, and S. Stillman. The Long-Term Impact of International Migration on Economic Decision-Making. 2016.

Goldberg, L. R. An alternative" description of personality": the big-five factor structure. Journal of personality and social psychology, 59(6):1216, 1990.

Groves, M. O. How important is your personality? Labor market returns to personality for women in the US and UK. Journal of Economic Psychology, 26(6):827-841, 2005.

Heineck, G. and S. Anger. The returns to cognitive abilities and personality traits in Germany. Labour Economics, 17(3):535-546, 2010.

Jaeger, D. A., T. Dohmen, A. Falk, D. Huffman, U. Sunde, and H. Bonin. Direct 
evidence on risk attitudes and migration. The Review of Economics and Statistics, 92(3):684-689, 2010.

John, O. P. and S. Srivastava. The Big Five trait taxonomy: History, measurement, and theoretical perspectives. Handbook of personality: Theory and research, 2(1999): 102-138, 1999.

Jokela, M. Personality predicts migration within and between US states. Journal of Research in Personality, 43(1):79-83, 2009.

Jokela, M., M. Elovainio, M. Kivimäki, and L. Keltikangas-Järvinen. Temperament and migration patterns in Finland. Psychological Science, 19(9):831-837, 2008.

Kautz, T., J. J. Heckman, R. Diris, B. Ter Weel, and L. Borghans. Fostering and measuring skills: Improving cognitive and non-cognitive skills to promote lifetime success. Technical report, National Bureau of Economic Research, 2014.

Koettl, J., O. Kupets, A. Olefir, and I. Santos. In search of opportunities? The barriers to more efficient internal labor mobility in Ukraine. IZA Journal of Labor \& Development, 3(1):21, 2014.

Kupets, O. Interregional migration in Ukraine: Spatial, economic and social factors. Demography Soc Econ, 2:22, 2014.

Lang, F. R., D. John, O. Lüdtke, J. Schupp, and G. G. Wagner. Short assessment of the Big Five: Robust across survey methods except telephone interviewing. Behavior research methods, 43(2):548-567, 2011.

Lehmann, H., A. Muravyev, and K. F. Zimmermann. The Ukrainian longitudinal monitoring survey: towards a better understanding of labor markets in transition. IZA Journal of Labor \& Development, 1(1):1, 2012.

Mykhnenko, V. and A. Swain. Ukraine's diverging space-economy: The Orange Revolution, post-soviet development models and regional trajectories. European Urban and Regional Studies, 17(2):141-165, 2010.

Paulauskaite, Š. L., Elma, A. Endriulaitienè, et al. Big Five Personality Traits Linked with Migratory Intentions in Lithuanian Student Sample. Tarptautinis psichologijos žurnalas: Biopsichosocialinis požiuris, (7):41-58, 2010.

Pierre, G., M. L. Sanchez Puerta, A. Valerio, and T. Rajadel. STEP skills measurement surveys: innovative tools for assessing skills. 2014.

Pissarides, C. A. Search unemployment with on-the-job search. The Review of Economic Studies, 61(3):457-475, 1994.

Silventoinen, K., N. Hammar, E. Hedlund, M. Koskenvuo, T. Ronnemaa, and J. Kaprio. Selective international migration by social position, health behaviour and personality. The European Journal of Public Health, 18(2):150-155, 2008. 
Sjaastad, L. The costs and returns of human migration. Journal of Political Economy, 70(5 Pt 2):80-93, 1962.

Stark, O. The migration of labor. 1991.

Weel, B. t. The noncognitive determinants of labor market and behavioral outcomes: Introduction to the symposium. The Journal of Human Resources, 43(4):729-737, 2008. 


\section{Figures and Tables}

Figure 1: General risk index in urban and rural areas, in 2007 and 2012

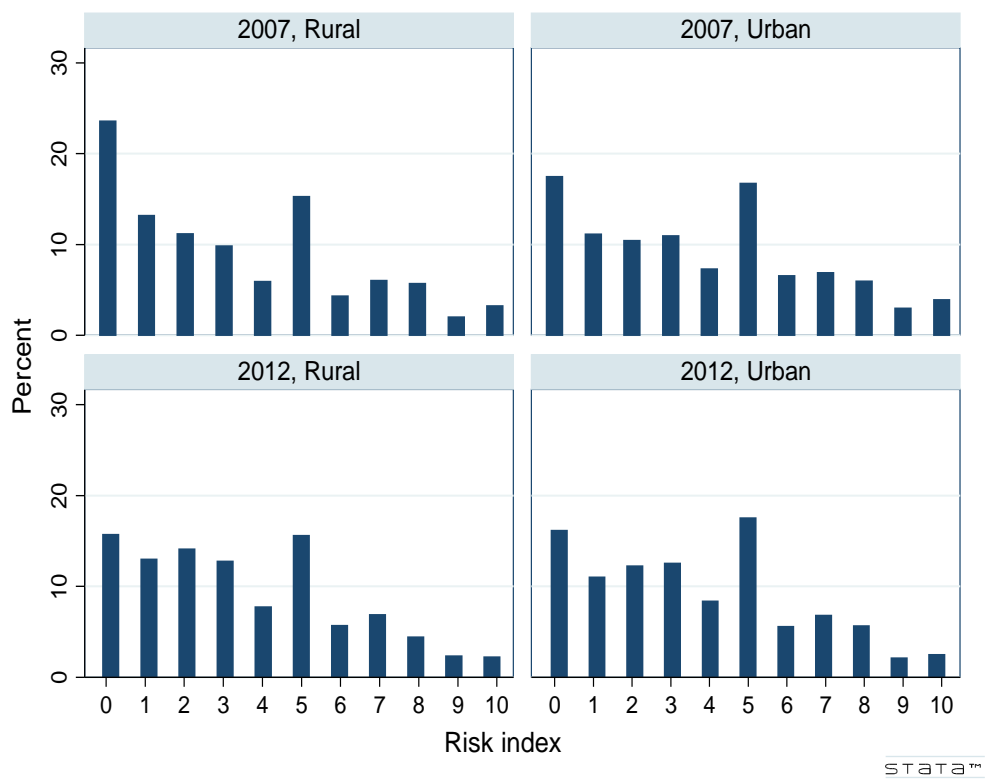


Table 1: Mapping 24 items into the Big Five factors

How do you see yourself?

3 Do you come up with ideas other people haven't thought of before?

11 Are you very interested in learning new things?

Openness

14 Do you enjoy beautiful things, like nature, art and music?

2 When doing a task, are you very careful?

6 Do you finish whatever you begin?

8 Do you work very hard? For example, do you keep working when others stop to take a break?

$12 *$ Do you prefer relaxation more than hard work?

Concientiousness

13 Do you enjoy working on things that take a very long time (at least several months) to complete?

17 Do you work very well and quickly?

21 Do you think carefully before you make an important decision?

1 Are you talkative?

4* Do you like to keep your opinions to yourself prefer to keep quiet when you have an opinion?

Extraversion

20 Are you outgoing and sociable, for example, do you make friends very easily?

9 Do you forgive other people easily?

16 Are you very polite to other people?

19 Are you generous to other people with your time or money?

Agreeableness

23 Do you ask for help when you don't understand something?

5* Are you relaxed during stressful situations?

7 Do people take advantage of you?

10 Do you tend to worry?

$15^{*}$ Do you think about how the things you do will affect you in the future?

Neuroticism

18 Do you get nervous easily?

22 Are people mean/not nice to you?

$24 *$ Do you think about how the things you do will affect other? 
Table 2: Summary statistics (2012)

\begin{tabular}{lrrr|rrr|rrr}
\hline & \multicolumn{3}{c|}{ Urban sample } & \multicolumn{3}{c|}{ Rural stayers } & \multicolumn{3}{c}{ Movers into urban } \\
\cline { 2 - 10 } & Obs & Mean & Std. Dev. & Obs & Mean & Std. Dev. & Obs & Mean & Std. Dev. \\
\hline Age & 3644 & 42.84 & 16.13 & 2308 & 47.31 & 14.98 & 48 & 32.44 & 13.00 \\
Female & 3644 & 0.56 & 0.50 & 2308 & 0.59 & 0.49 & 48 & 0.58 & 0.50 \\
Ukranian language & 3644 & 0.30 & 0.46 & 2308 & 0.68 & 0.47 & 48 & 0.42 & 0.50 \\
Married & 3643 & 0.62 & 0.48 & 2308 & 0.66 & 0.47 & 48 & 0.77 & 0.42 \\
Number of children & 3640 & 1.23 & 0.95 & 2308 & 1.67 & 1.05 & 48 & 0.88 & 0.87 \\
Education level & 3637 & 3.03 & 0.88 & 2305 & 2.77 & 0.86 & 48 & 3.23 & 0.93 \\
Employed & 3644 & 0.51 & 0.50 & 2308 & 0.45 & 0.50 & 48 & 0.71 & 0.46 \\
Household income & 3644 & 4894.72 & 3484.40 & 2308 & 3648.39 & 2497.21 & 48 & 4198.10 & 2212.40 \\
Risk indicator & 3527 & 0.22 & 0.42 & 2270 & 0.18 & 0.39 & 48 & 0.23 & 0.42 \\
Risk index & 3527 & 3.62 & 2.71 & 2270 & 3.20 & 2.64 & 48 & 3.75 & 2.61 \\
Openness & 3643 & 3.05 & 0.54 & 2308 & 3.01 & 0.57 & 48 & 3.19 & 0.52 \\
Conscientiousness & 3643 & 2.87 & 0.47 & 2308 & 2.99 & 0.44 & 48 & 2.94 & 0.48 \\
Extraversion & 3643 & 2.63 & 0.62 & 2308 & 2.65 & 0.60 & 48 & 2.66 & 0.61 \\
Agreeableness & 3641 & 2.85 & 0.52 & 2303 & 2.96 & 0.49 & 48 & 3.05 & 0.52 \\
Neuroticism & 3643 & 2.09 & 0.41 & 2308 & 2.10 & 0.40 & 48 & 2.02 & 0.41 \\
\hline
\end{tabular}

Source: Autors' tabulations from the 2012 wave of the ULMS

Table 3: Effects of the Big Five on migration

\begin{tabular}{|c|c|c|c|c|c|c|c|c|c|}
\hline & $\begin{array}{c}(1) \\
\text { rural-urban }\end{array}$ & $\begin{array}{c}(2) \\
\text { rural-urban }\end{array}$ & $\begin{array}{c}(3) \\
\text { rural-urban }\end{array}$ & $\begin{array}{c}\text { (4) } \\
\text { rural-city }\end{array}$ & $\begin{array}{c}\text { (5) } \\
\text { rural-city }\end{array}$ & $\begin{array}{c}\text { (6) } \\
\text { rural-city }\end{array}$ & $\begin{array}{c}(7) \\
\text { rural-town }\end{array}$ & $\begin{array}{c}(8) \\
\text { rural-town }\end{array}$ & $\begin{array}{c}(9) \\
\text { rural-town }\end{array}$ \\
\hline Openness & $\begin{array}{c}0.008^{* * *} \\
(0.002)\end{array}$ & $\begin{array}{l}0.003^{*} \\
(0.002)\end{array}$ & $\begin{array}{c}0.001 \\
(0.002)\end{array}$ & $\begin{array}{c}0.004^{* * *} \\
(0.001)\end{array}$ & $\begin{array}{c}0.002^{* *} \\
(0.001)\end{array}$ & $\begin{array}{c}0.001^{*} \\
(0.001)\end{array}$ & $\begin{array}{c}0.003^{* *} \\
(0.001)\end{array}$ & $\begin{array}{c}0.001 \\
(0.001)\end{array}$ & $\begin{array}{c}0.000 \\
(0.001)\end{array}$ \\
\hline Conscientiousness & $\begin{array}{c}-0.013^{* * *} \\
(0.002)\end{array}$ & $\begin{array}{c}-0.008^{* * *} \\
(0.002)\end{array}$ & $\begin{array}{c}-0.008^{* * *} \\
(0.002)\end{array}$ & $\begin{array}{c}-0.008^{* * *} \\
(0.001)\end{array}$ & $\begin{array}{c}-0.005^{* * *} * \\
(0.001)\end{array}$ & $\begin{array}{c}-0.004^{* * *} \\
(0.001)\end{array}$ & $\begin{array}{c}-0.005^{* * *} \\
(0.001)\end{array}$ & $\begin{array}{c}-0.002^{* *} \\
(0.001)\end{array}$ & $\begin{array}{c}-0.002^{* *} \\
(0.001)\end{array}$ \\
\hline Extraversion & $\begin{array}{c}-0.002 \\
(0.002)\end{array}$ & $\begin{array}{l}-0.002 \\
(0.002)\end{array}$ & $\begin{array}{l}-0.000 \\
(0.001)\end{array}$ & $\begin{array}{c}-0.002^{*} \\
(0.001)\end{array}$ & $\begin{array}{c}-0.002^{* *} \\
(0.001)\end{array}$ & $\begin{array}{c}-0.001^{*} \\
(0.001)\end{array}$ & $\begin{array}{c}0.001 \\
(0.001)\end{array}$ & $\begin{array}{c}0.001 \\
(0.001)\end{array}$ & $\begin{array}{c}0.001 \\
(0.001)\end{array}$ \\
\hline Agreeableness & $\begin{array}{c}-0.008^{* * *} * \\
(0.002)\end{array}$ & $\begin{array}{c}-0.005^{* * *} * \\
(0.002)\end{array}$ & $\begin{array}{c}-0.005^{* * *} * \\
(0.002)\end{array}$ & $\begin{array}{c}-0.003^{* *} \\
(0.002)\end{array}$ & $\begin{array}{c}-0.002 \\
(0.001)\end{array}$ & $\begin{array}{l}-0.001 \\
(0.001)\end{array}$ & $\begin{array}{c}-0.004^{* * *} \\
(0.001)\end{array}$ & $\begin{array}{c}-0.003^{* * *} \\
(0.001)\end{array}$ & $\begin{array}{c}-0.003^{* * *} \\
(0.001)\end{array}$ \\
\hline Neuroticism & $\begin{array}{c}-0.004^{*} \\
(0.002)\end{array}$ & $\begin{array}{l}-0.003 \\
(0.002)\end{array}$ & $\begin{array}{l}-0.002 \\
(0.002)\end{array}$ & $\begin{array}{l}-0.002 \\
(0.002)\end{array}$ & $\begin{array}{l}-0.001 \\
(0.001)\end{array}$ & $\begin{array}{l}-0.001 \\
(0.001)\end{array}$ & $\begin{array}{c}-0.003^{*} \\
(0.001)\end{array}$ & $\begin{array}{c}-0.002^{*} \\
(0.001)\end{array}$ & $\begin{array}{l}-0.001 \\
(0.001)\end{array}$ \\
\hline Age & & $\begin{array}{l}-0.001^{*} \\
(0.001)\end{array}$ & $\begin{array}{c}-0.002^{* *} \\
(0.001)\end{array}$ & & $\begin{array}{c}-0.001^{* *} \\
(0.000)\end{array}$ & $\begin{array}{c}-0.001^{*} \\
(0.000)\end{array}$ & & $\begin{array}{c}0.000 \\
(0.000)\end{array}$ & $\begin{array}{l}-0.000 \\
(0.000)\end{array}$ \\
\hline Age squared & & $\begin{array}{c}0.001 \\
(0.001)\end{array}$ & $\begin{array}{l}0.002^{*} \\
(0.001)\end{array}$ & & $\begin{array}{c}0.001 \\
(0.001)\end{array}$ & $\begin{array}{c}0.001 \\
(0.001)\end{array}$ & & $\begin{array}{l}-0.000 \\
(0.000)\end{array}$ & $\begin{array}{l}0.000 \\
(0.001)\end{array}$ \\
\hline Female & & $\begin{array}{c}0.001 \\
(0.003)\end{array}$ & $\begin{array}{c}0.002 \\
(0.003)\end{array}$ & & $\begin{array}{c}0.001 \\
(0.002)\end{array}$ & $\begin{array}{c}0.001 \\
(0.001)\end{array}$ & & $\begin{array}{c}0.000 \\
(0.002)\end{array}$ & $\begin{array}{c}0.001 \\
(0.002)\end{array}$ \\
\hline Ukrainian language & & $\begin{array}{c}-0.041^{* * *} * \\
(0.005)\end{array}$ & $\begin{array}{c}-0.034^{* * *} \\
(0.005)\end{array}$ & & $\begin{array}{c}-0.012^{* * *} * \\
(0.003)\end{array}$ & $\begin{array}{c}-0.008^{* * *} \\
(0.002)\end{array}$ & & $\begin{array}{c}-0.029^{* * *} \\
(0.004)\end{array}$ & $\begin{array}{c}-0.024^{* * *} \\
(0.004)\end{array}$ \\
\hline Married & & & $\begin{array}{c}0.000 \\
(0.003)\end{array}$ & & & $\begin{array}{l}-0.002 \\
(0.002)\end{array}$ & & & $\begin{array}{c}0.002 \\
(0.002)\end{array}$ \\
\hline Number of children & & & $\begin{array}{l}-0.002 \\
(0.002)\end{array}$ & & & $\begin{array}{l}-0.002 \\
(0.001)\end{array}$ & & & $\begin{array}{l}-0.000 \\
(0.001)\end{array}$ \\
\hline Employed & & & $\begin{array}{c}0.001 \\
(0.003)\end{array}$ & & & $\begin{array}{l}-0.001 \\
(0.002)\end{array}$ & & & $\begin{array}{c}0.002 \\
(0.002)\end{array}$ \\
\hline Log of household income & & & $\begin{array}{c}0.007^{* * *} \\
(0.002)\end{array}$ & & & $\begin{array}{c}0.003^{* * *} \\
(0.001)\end{array}$ & & & $\begin{array}{c}0.003^{* *} \\
(0.001)\end{array}$ \\
\hline Education: Secondary & & & $\begin{array}{c}0.002 \\
(0.003)\end{array}$ & & & $\begin{array}{c}0.005^{* *} \\
(0.002)\end{array}$ & & & $\begin{array}{c}-0.004^{*} \\
(0.002)\end{array}$ \\
\hline Education: Vocational & & & $\begin{array}{c}0.010^{* * * *} \\
(0.003)\end{array}$ & & & $\begin{array}{c}0.006^{* * *} \\
(0.002)\end{array}$ & & & $\begin{array}{c}0.002 \\
(0.002)\end{array}$ \\
\hline Education: Higher & & & $\begin{array}{c}0.018^{* * * *} \\
(0.006)\end{array}$ & & & $\begin{array}{c}0.007^{* *} \\
(0.003)\end{array}$ & & & $\begin{array}{l}0.007^{*} \\
(0.004)\end{array}$ \\
\hline Observations & 6,164 & 6,153 & 5,729 & 6,079 & 6,068 & 5,644 & 6,077 & 6,066 & 5,649 \\
\hline
\end{tabular}

Note: The table shows marginal effects from probit estimation, evaluated at sample mean. The Big Five factors -openness, conscientiousness, extraversion, agreeableness, neuroticism- are standardized averages with a mean of 0 and standard deviation of 1 . The covariates of age, age square, number of children and log of household income are continuous variables, while female, Ukrainian language, married and employed refer to dummy variables. The control for education is a categorical variable with the reference category of basic secondary level education. These control variables are lagged, i.e. the values are taken from the previous wave. Robust standard errors in parentheses; ${ }^{* * *} \mathrm{p}<0.01,{ }^{* *} \mathrm{p}<0.05,{ }^{*} \mathrm{p}<0.1$. 
Table 4: Effects of the Big Five and risk on migration

\begin{tabular}{|c|c|c|c|c|c|c|c|c|c|}
\hline & $\begin{array}{c}(1) \\
\text { rural-urban }\end{array}$ & $\begin{array}{c}(2) \\
\text { rural-urban }\end{array}$ & $\begin{array}{c}(3) \\
\text { rural-urban }\end{array}$ & $\begin{array}{c}\text { (4) } \\
\text { rural-city }\end{array}$ & $\begin{array}{c}(5) \\
\text { rural-city }\end{array}$ & $\begin{array}{c}(6) \\
\text { rural-city }\end{array}$ & $\begin{array}{c}(7) \\
\text { rural-town }\end{array}$ & $\begin{array}{c}8) \\
\text { rural-town }\end{array}$ & $\begin{array}{c}(9) \\
\text { rural-town }\end{array}$ \\
\hline Openness & $\begin{array}{c}0.007^{* * *} \\
(0.002)\end{array}$ & $\begin{array}{c}0.003^{*} \\
(0.002)\end{array}$ & $\begin{array}{c}0.001 \\
(0.002)\end{array}$ & $\begin{array}{c}0.004^{* * *} \\
(0.001)\end{array}$ & $\begin{array}{c}0.002^{* *} \\
(0.001)\end{array}$ & $\begin{array}{l}0.001^{*} \\
(0.001)\end{array}$ & $\begin{array}{c}0.003^{* *} \\
(0.001)\end{array}$ & $\begin{array}{c}0.001 \\
(0.001)\end{array}$ & $\begin{array}{c}0.000 \\
(0.001)\end{array}$ \\
\hline Conscientiousness & $\begin{array}{c}-0.013^{* * *} \\
(0.002)\end{array}$ & $\begin{array}{c}-0.008^{* * *} \\
(0.002)\end{array}$ & $\begin{array}{c}-0.008 * * * \\
(0.002)\end{array}$ & $\begin{array}{c}-0.008^{* * *} \\
(0.001)\end{array}$ & $\begin{array}{c}-0.005^{* * *} \\
(0.001)\end{array}$ & $\begin{array}{c}-0.004^{* * *} \\
(0.001)\end{array}$ & $\begin{array}{c}-0.005^{* * *} \\
(0.001)\end{array}$ & $\begin{array}{c}-0.002^{* *} \\
(0.001)\end{array}$ & $\begin{array}{c}-0.002^{* *} \\
(0.001)\end{array}$ \\
\hline Extraversion & $\begin{array}{l}-0.002 \\
(0.002)\end{array}$ & $\begin{array}{l}-0.001 \\
(0.002)\end{array}$ & $\begin{array}{l}-0.000 \\
(0.001)\end{array}$ & $\begin{array}{c}-0.003^{* *} \\
(0.001)\end{array}$ & $\begin{array}{c}-0.002^{* *} \\
(0.001)\end{array}$ & $\begin{array}{l}-0.001^{*} \\
(0.001)\end{array}$ & $\begin{array}{c}0.001 \\
(0.001)\end{array}$ & $\begin{array}{l}0.001 \\
(0.001)\end{array}$ & $\begin{array}{c}0.001 \\
(0.001)\end{array}$ \\
\hline Agreeableness & $\begin{array}{c}-0.008^{* * *} \\
(0.002)\end{array}$ & $\begin{array}{c}-0.005^{* * *} \\
(0.002)\end{array}$ & $\begin{array}{c}-0.005^{* * *} \\
(0.002)\end{array}$ & $\begin{array}{c}-0.003^{* *} \\
(0.002)\end{array}$ & $\begin{array}{l}-0.002 \\
(0.001)\end{array}$ & $\begin{array}{l}-0.001 \\
(0.001)\end{array}$ & $\begin{array}{c}-0.004^{* * *} \\
(0.001)\end{array}$ & $\begin{array}{c}-0.003^{* * *} \\
(0.001)\end{array}$ & $\begin{array}{c}-0.002^{* * *} \\
(0.001)\end{array}$ \\
\hline Neuroticism & $\begin{array}{c}-0.004^{*} \\
(0.002)\end{array}$ & $\begin{array}{l}-0.003 \\
(0.002)\end{array}$ & $\begin{array}{l}-0.002 \\
(0.002)\end{array}$ & $\begin{array}{l}-0.001 \\
(0.001)\end{array}$ & $\begin{array}{l}-0.001 \\
(0.001)\end{array}$ & $\begin{array}{l}-0.001 \\
(0.001)\end{array}$ & $\begin{array}{l}-0.002^{*} \\
(0.001)\end{array}$ & $\begin{array}{l}-0.002^{*} \\
(0.001)\end{array}$ & $\begin{array}{l}-0.001 \\
(0.001)\end{array}$ \\
\hline Risk indicator & $\begin{array}{l}-0.001 \\
(0.005)\end{array}$ & $\begin{array}{l}-0.001 \\
(0.004)\end{array}$ & $\begin{array}{l}-0.001 \\
(0.003)\end{array}$ & $\begin{array}{l}0.008^{* *} \\
(0.004)\end{array}$ & $\begin{array}{l}0.005^{* *} \\
(0.003)\end{array}$ & $\begin{array}{l}0.003^{*} \\
(0.002)\end{array}$ & $\begin{array}{c}-0.009 * * * \\
(0.003)\end{array}$ & $\begin{array}{c}-0.005^{* * *} \\
(0.002)\end{array}$ & $\begin{array}{c}-0.004^{* *} \\
(0.002)\end{array}$ \\
\hline $\begin{array}{l}\text { Covariates } \\
\text { Set } 1 \\
\text { Set } 2\end{array}$ & $\begin{array}{l}\text { No } \\
\text { No }\end{array}$ & $\begin{array}{l}\text { Yes } \\
\text { No }\end{array}$ & $\begin{array}{l}\text { Yes } \\
\text { Yes }\end{array}$ & $\begin{array}{l}\text { No } \\
\text { No }\end{array}$ & $\begin{array}{l}\text { Yes } \\
\text { No }\end{array}$ & $\begin{array}{l}\text { Yes } \\
\text { Yes }\end{array}$ & $\begin{array}{l}\text { No } \\
\text { No }\end{array}$ & $\begin{array}{l}\text { Yes } \\
\text { No }\end{array}$ & $\begin{array}{l}\text { Yes } \\
\text { Yes }\end{array}$ \\
\hline Observations & 6,125 & 6,114 & 5,692 & 6,041 & 6,030 & 5,608 & 6,038 & 6,027 & 5,612 \\
\hline
\end{tabular}

Note: The table shows marginal effects from probit estimation, evaluated at sample mean. The Big Five factors -openness, conscientiousness, extraversion, agreeableness, neuroticism- are standardized averages with a mean of 0 and standard deviation of 1 . The risk indicator is a dummy variable for values greater than 5 on a 11-point scale. The covariates of age, age square, number of children and log of household income are continuous variables, while female, Ukrainian language, married and employed refer to dummy variables. The control for education is a categorical variable with the reference category of basic secondary level education. These control variables are lagged, i.e., the values are taken from the previous wave. Robust standard errors in parentheses; ${ }^{* *} \mathrm{p}<0.01,{ }^{* *} \mathrm{p}<0.05,{ }^{*} \mathrm{p}<0.1$.

Table 5: Effects of the Big Five and risk on migration, conditioning on regional controls

\begin{tabular}{|c|c|c|c|c|c|c|c|c|c|}
\hline & $\begin{array}{c}(1) \\
\text { rural-urban }\end{array}$ & $\begin{array}{c}(2) \\
\text { rural-urban }\end{array}$ & $\begin{array}{c}(3) \\
\text { rural-urban }\end{array}$ & $\begin{array}{c}(4) \\
\text { rural-city }\end{array}$ & $\begin{array}{c}(5) \\
\text { rural-city }\end{array}$ & $\begin{array}{c}(6) \\
\text { rural-city }\end{array}$ & $\begin{array}{c}(7) \\
\text { rural-town }\end{array}$ & $\begin{array}{c}(8) \\
\text { rural-town }\end{array}$ & $\begin{array}{c}(9) \\
\text { rural-town }\end{array}$ \\
\hline Openness & $\begin{array}{l}0.003^{*} \\
(0.002)\end{array}$ & $\begin{array}{l}0.003^{*} \\
(0.002)\end{array}$ & $\begin{array}{l}0.003^{*} \\
(0.002)\end{array}$ & $\begin{array}{c}0.002^{* *} \\
(0.001)\end{array}$ & $\begin{array}{c}0.002^{* *} \\
(0.001)\end{array}$ & $\begin{array}{c}0.002^{* *} \\
(0.001)\end{array}$ & $\begin{array}{c}0.001 \\
(0.001)\end{array}$ & $\begin{array}{c}0.001 \\
(0.001)\end{array}$ & $\begin{array}{c}0.001 \\
(0.001)\end{array}$ \\
\hline Conscientiousness & $\begin{array}{c}-0.008^{* * *} \\
(0.002)\end{array}$ & $\begin{array}{c}-0.008^{* * *} \\
(0.002)\end{array}$ & $\begin{array}{c}-0.007^{* * *} \\
(0.002)\end{array}$ & $\begin{array}{c}-0.005^{* * *} \\
(0.001)\end{array}$ & $\begin{array}{c}-0.005^{* * *} \\
(0.001)\end{array}$ & $\begin{array}{c}-0.004^{* * *} \\
(0.001)\end{array}$ & $\begin{array}{c}-0.002^{* *} \\
(0.001)\end{array}$ & $\begin{array}{c}-0.002^{* *} \\
(0.001)\end{array}$ & $\begin{array}{r}-0.002^{*} \\
(0.001)\end{array}$ \\
\hline Extraversion & $\begin{array}{l}-0.001 \\
(0.002)\end{array}$ & $\begin{array}{l}-0.002 \\
(0.002)\end{array}$ & $\begin{array}{l}-0.002 \\
(0.001)\end{array}$ & $\begin{array}{c}-0.002^{* *} \\
(0.001)\end{array}$ & $\begin{array}{c}-0.002^{* *} \\
(0.001)\end{array}$ & $\begin{array}{c}-0.002^{* *} \\
(0.001)\end{array}$ & $\begin{array}{c}0.001 \\
(0.001)\end{array}$ & $\begin{array}{c}0.001 \\
(0.001)\end{array}$ & $\begin{array}{c}0.001 \\
(0.001)\end{array}$ \\
\hline Agreeableness & $\begin{array}{c}-0.005^{* * *} \\
(0.002)\end{array}$ & $\begin{array}{c}-0.005^{* *} \\
(0.002)\end{array}$ & $\begin{array}{l}-0.003 \\
(0.002)\end{array}$ & $\begin{array}{l}-0.002 \\
(0.001)\end{array}$ & $\begin{array}{l}-0.002 \\
(0.001)\end{array}$ & $\begin{array}{l}-0.001 \\
(0.001)\end{array}$ & $\begin{array}{c}-0.003^{* * *} \\
(0.001)\end{array}$ & $\begin{array}{c}-0.003^{* * *} \\
(0.001)\end{array}$ & $\begin{array}{c}-0.002^{* *} \\
(0.001)\end{array}$ \\
\hline Neuroticism & $\begin{array}{l}-0.003 \\
(0.002)\end{array}$ & $\begin{array}{l}-0.003 \\
(0.002)\end{array}$ & $\begin{array}{l}-0.001 \\
(0.002)\end{array}$ & $\begin{array}{c}-0.001 \\
(0.001)\end{array}$ & $\begin{array}{l}-0.001 \\
(0.001)\end{array}$ & $\begin{array}{l}-0.000 \\
(0.001)\end{array}$ & $\begin{array}{l}-0.002^{*} \\
(0.001)\end{array}$ & $\begin{array}{l}-0.002 \\
(0.001)\end{array}$ & $\begin{array}{l}-0.001 \\
(0.001)\end{array}$ \\
\hline Risk indicator & $\begin{array}{l}-0.001 \\
(0.004)\end{array}$ & $\begin{array}{c}-0.001 \\
(0.003)\end{array}$ & $\begin{array}{c}0.002 \\
(0.004)\end{array}$ & $\begin{array}{c}0.005^{* *} \\
(0.003)\end{array}$ & $\begin{array}{c}0.005^{* *} \\
(0.003)\end{array}$ & $\begin{array}{c}0.006^{* *} \\
(0.003)\end{array}$ & $\begin{array}{c}-0.005^{* * *} \\
(0.002)\end{array}$ & $\begin{array}{c}-0.004^{* * *} \\
(0.002)\end{array}$ & $\begin{array}{r}-0.003^{*} \\
(0.002)\end{array}$ \\
\hline $\begin{array}{l}\text { Regional covariates } \\
\text { Unemployment rate }\end{array}$ & & $\begin{array}{c}-0.003^{* * *} \\
(0.001)\end{array}$ & & & $\begin{array}{c}-0.001^{* *} \\
(0.000)\end{array}$ & & & $\begin{array}{c}-0.001^{* * *} \\
(0.000)\end{array}$ & \\
\hline Log of GDP & & & $\begin{array}{c}0.016^{* * *} \\
(0.002)\end{array}$ & & & $\begin{array}{c}0.007 * * * \\
(0.001)\end{array}$ & & & $\begin{array}{c}0.006^{* * *} \\
(0.001)\end{array}$ \\
\hline Observations & 6,114 & 6,114 & 6,114 & 6,030 & 6,030 & 6,030 & 6,027 & 6,027 & 6,027 \\
\hline
\end{tabular}

Note: The table shows marginal effects from probit estimation, evaluated at sample means. The Big Five factors -openness, conscientiousness, extraversion, agreeableness, neuroticism- are standardized averages with a mean of 0 and standard deviation of 1 . The risk indicator is a dummy variable for values greater than 5 on a 11-point scale. Regional controls include unemployment rate and $\log$ of GDP at oblast level. All specifications also include individual-level controls of age, age squared, female and Ukrainian language, as well as year fixed effects. The covariates are lagged variables, i.e., the values are taken from the previous wave. Robust standard errors in parentheses; ${ }^{* * *} \mathrm{p}<0.01,{ }^{* *} \mathrm{p}<0.05,{ }^{*} \mathrm{p}<0.1$. 
Table 6: Complementarity between the Big Five and risk in explaining the migration propensity

\begin{tabular}{lclccc}
\hline & $\|($ null) & $\|($ (model) & $d f$ & AIC & Pseudo R2 \\
\cline { 2 - 6 } & \multicolumn{5}{c}{ Rural-to-urban migration } \\
Risk & -780.20 & -706.85 & 6 & 1425.70 & 0.094 \\
Big Five & -780.20 & -685.15 & 10 & 1390.31 & 0.122 \\
Risk and Big Five & -780.20 & -685.05 & 11 & 1392.10 & 0.122 \\
\hline \multicolumn{5}{c}{ Rural-to-city migration } \\
Risk & -455.13 & -419.52 & 6 & 851.04 & 0.078 \\
Big Five & -455.13 & -402.61 & 10 & 825.21 & 0.115 \\
Risk and Big Five & -455.13 & -401.27 & 11 & 824.53 & 0.118 \\
\hline & \multicolumn{5}{c}{ Rural-to-town migration } \\
Risk & -442.36 & -388.87 & 6 & 789.73 & 0.121 \\
Big Five & -442.36 & -383.38 & 10 & 786.76 & 0.133 \\
Risk and Big Five & -442.36 & -380.43 & 11 & 782.87 & 0.140 \\
\hline
\end{tabular}

Note: AIC refers to the Akaike's information criterion. The AIC is a goodness-of-fit measure calculated after the estimation of probit models. The model with the smaller value of the information criterion is considered to be better. All specifications include individual-level controls of age, age square, female, and Ukrainian language. The number of observations varies for the different migration outcomes: rural-to-urban migration (6114), rural-to-city (6030), and rural-to-town (6027). 
Table 7: Effects of the Big Five and risk on migration: Migration occurs between 2007-2012, after risk is measured in 2007

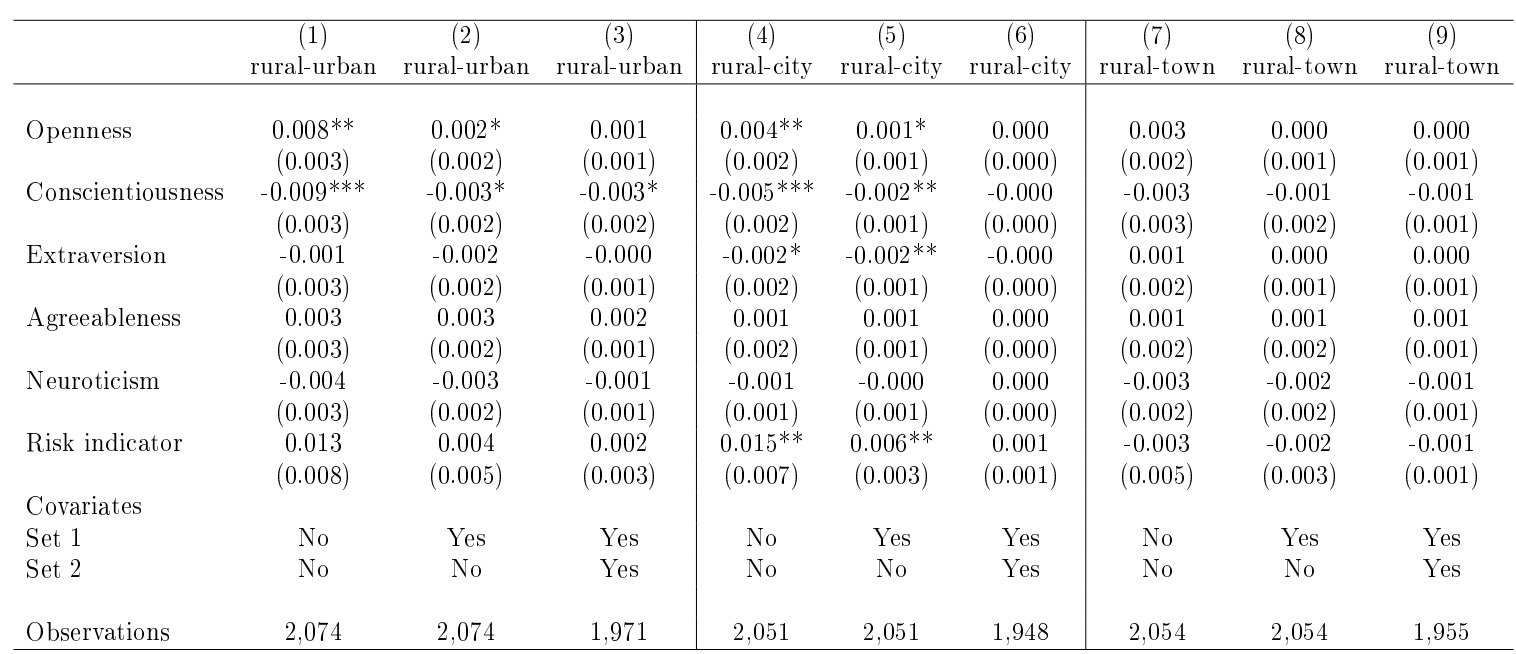

Note: The table shows marginal effects from probit estimation, evaluated at sample mean. The outcome variable, measured in 2012 , captures the migration that occurred between 2007 and 2012. The risk indicator, measured in 2007, denotes a dummy variable for values greater than 5 on a scale from 0 to 10 . Set 1 represents covariates of age, age square, female and Ukrainian language, while Set 2 refers to covariates of married, number of children, education level, employed, and log of net household income. The covariates are measured in 2007. Robust standard errors in parentheses; ${ }^{* *} \mathrm{p}<0.01,{ }^{* *} \mathrm{p}<0.05,{ }^{*} \mathrm{p}<0.1$.

Table 8: Reverse causality check for risk: The impact of migration on the risk measure

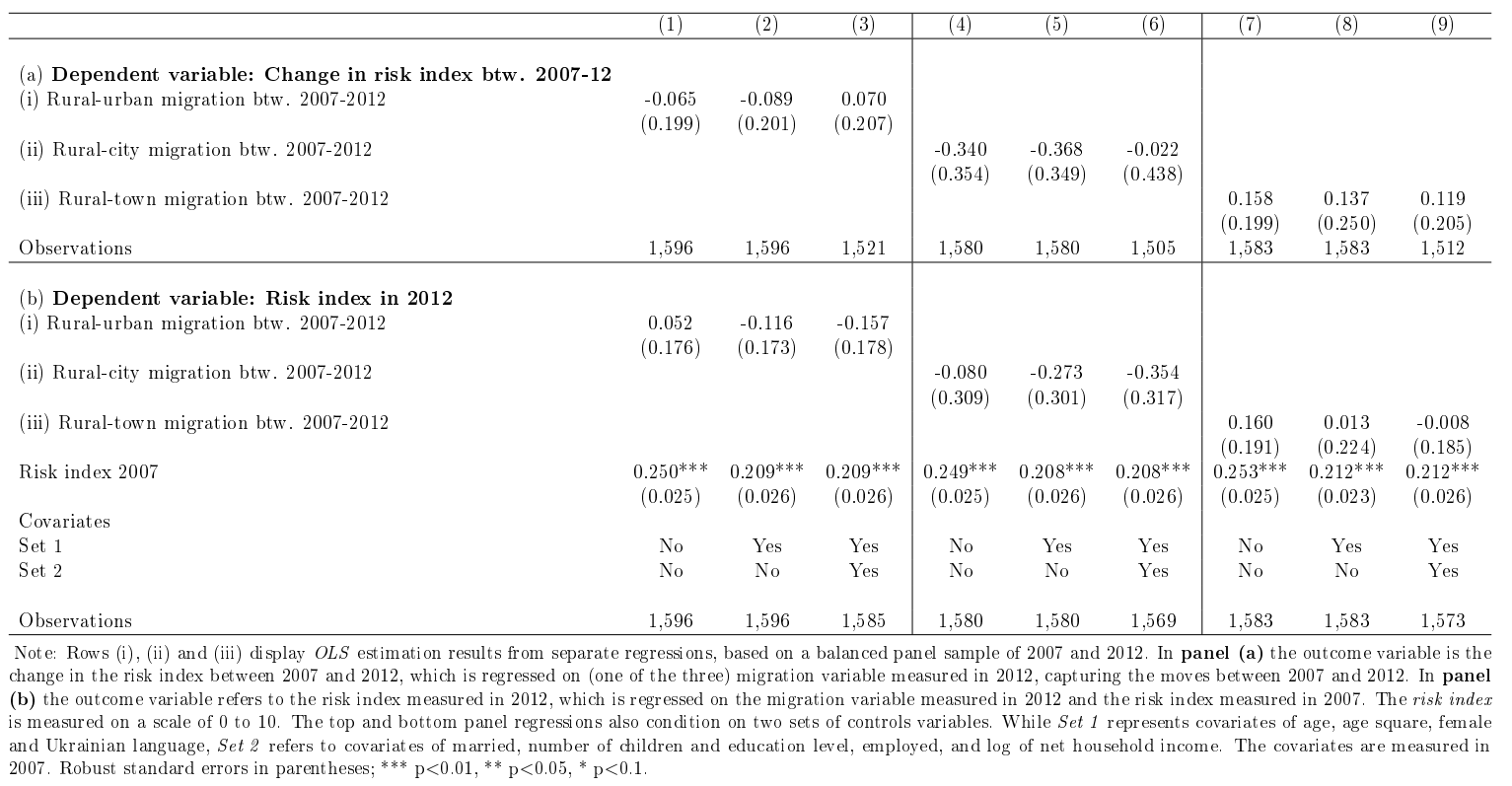


Table 9: Age-free effects of the Big Five on migration

\begin{tabular}{|c|c|c|c|c|c|c|c|c|c|}
\hline & $\begin{array}{c}(1) \\
\text { rural-urban }\end{array}$ & $\begin{array}{c}(2) \\
\text { rural-urban }\end{array}$ & $\begin{array}{c}(3) \\
\text { rural-urban }\end{array}$ & $\begin{array}{c}(4) \\
\text { rural-city }\end{array}$ & $\begin{array}{c}(5) \\
\text { rural-city }\end{array}$ & $\begin{array}{c}(6) \\
\text { rural-city }\end{array}$ & $\begin{array}{c}(7) \\
\text { rural-town }\end{array}$ & $\begin{array}{c}\text { (8) } \\
\text { rural-town }\end{array}$ & $\begin{array}{c}\text { (9) } \\
\text { rural-town }\end{array}$ \\
\hline Openness & $\begin{array}{c}0.005^{* *} \\
(0.002)\end{array}$ & $\begin{array}{l}0.003^{*} \\
(0.002)\end{array}$ & $\begin{array}{c}0.001 \\
(0.002)\end{array}$ & $\begin{array}{l}0.002^{*} \\
(0.002)\end{array}$ & $\begin{array}{c}0.002^{* *} \\
(0.001)\end{array}$ & $\begin{array}{c}0.001^{*} \\
(0.001)\end{array}$ & $\begin{array}{l}0.003^{*} \\
(0.001)\end{array}$ & $\begin{array}{c}0.001 \\
(0.001)\end{array}$ & $\begin{array}{c}0.000 \\
(0.001)\end{array}$ \\
\hline Conscientiousness & $\begin{array}{c}-0.012^{* * *} \\
(0.002)\end{array}$ & $\begin{array}{c}-0.008^{* * *} \\
(0.002)\end{array}$ & $\begin{array}{c}-0.009^{* * *} \\
(0.002)\end{array}$ & $\begin{array}{c}-0.007^{* * *} \\
(0.002)\end{array}$ & $\begin{array}{c}-0.005^{* * *} \\
(0.001)\end{array}$ & $\begin{array}{c}-0.005^{* * *} \\
(0.001)\end{array}$ & $\begin{array}{c}-0.005^{* * *} \\
(0.001)\end{array}$ & $\begin{array}{c}-0.002^{* *} \\
(0.001)\end{array}$ & $\begin{array}{c}-0.003^{* *} \\
(0.001)\end{array}$ \\
\hline Extraversion & $\begin{array}{l}-0.002 \\
(0.002)\end{array}$ & $\begin{array}{l}-0.002 \\
(0.002)\end{array}$ & $\begin{array}{l}-0.001 \\
(0.001)\end{array}$ & $\begin{array}{c}-0.003^{* *} \\
(0.001)\end{array}$ & $\begin{array}{c}-0.002^{* *} \\
(0.001)\end{array}$ & $\begin{array}{l}-0.001 \\
(0.001)\end{array}$ & $\begin{array}{c}0.001 \\
(0.001)\end{array}$ & $\begin{array}{c}0.001 \\
(0.001)\end{array}$ & $\begin{array}{c}0.001 \\
(0.001)\end{array}$ \\
\hline Agreeableness & $\begin{array}{c}-0.006 * * * \\
(0.002)\end{array}$ & $\begin{array}{c}-0.005^{* * *} \\
(0.002)\end{array}$ & $\begin{array}{c}-0.005^{* * *} \\
(0.002)\end{array}$ & $\begin{array}{l}-0.003 \\
(0.002)\end{array}$ & $\begin{array}{l}-0.002 \\
(0.001)\end{array}$ & $\begin{array}{l}-0.002 \\
(0.001)\end{array}$ & $\begin{array}{c}-0.004^{* * *} \\
(0.002)\end{array}$ & $\begin{array}{c}-0.003^{* * *} \\
(0.001)\end{array}$ & $\begin{array}{c}-0.003^{* * *} \\
(0.001)\end{array}$ \\
\hline Neuroticism & $\begin{array}{c}-0.004^{*} \\
(0.002)\end{array}$ & $\begin{array}{c}-0.003^{*} \\
(0.002)\end{array}$ & $\begin{array}{c}-0.003^{*} \\
(0.002)\end{array}$ & $\begin{array}{l}-0.001 \\
(0.002)\end{array}$ & $\begin{array}{l}-0.001 \\
(0.001)\end{array}$ & $\begin{array}{l}-0.001 \\
(0.001)\end{array}$ & $\begin{array}{c}-0.003^{*} \\
(0.002)\end{array}$ & $\begin{array}{r}-0.002^{*} \\
(0.001)\end{array}$ & $\begin{array}{c}-0.002^{*} \\
(0.001)\end{array}$ \\
\hline $\begin{array}{l}\text { Covariates } \\
\text { Set } 1 \\
\text { Set } 2\end{array}$ & $\begin{array}{l}\text { No } \\
\text { No }\end{array}$ & $\begin{array}{l}\text { Yes } \\
\text { No }\end{array}$ & $\begin{array}{l}\text { Yes } \\
\text { Yes }\end{array}$ & $\begin{array}{l}\text { No } \\
\text { No }\end{array}$ & $\begin{array}{l}\text { Yes } \\
\text { No }\end{array}$ & $\begin{array}{l}\text { Yes } \\
\text { Yes }\end{array}$ & $\begin{array}{l}\text { No } \\
\text { No }\end{array}$ & $\begin{array}{l}\text { Yes } \\
\text { No }\end{array}$ & $\begin{array}{l}\text { Yes } \\
\text { Yes }\end{array}$ \\
\hline Observations & 6,164 & 6,153 & 5,729 & 6,079 & 6,068 & 5,644 & 6,077 & 6,066 & 5,649 \\
\hline
\end{tabular}

Note: The table shows marginal effects from probit estimation, evaluated at sample mean. The Big Five factors -openness, conscientiousness, extraversion, agreeableness, neuroticism- are the predicted residuals from the regressions of the Big Five on age and age square. The predicted residuals are standardized with a mean of 0 and standard deviation of 1 . Set 1 represents covariates of age, age square, female and Ukrainian language, while Set 2 refers to covariates of married, number of children, education level, employed, and log of total household income. These control variables are lagged, i.e. the values are taken from the previous wave. Bootstrapped standard errors in parentheses (with a replication number of 500); *** $\mathrm{p}<0.01,{ }^{* *} \mathrm{p}<0.05,{ }^{*} \mathrm{p}<0.1$. 


\section{Appendix Tables}

Table A.1 Summary statistics of 2004 and 2007

\begin{tabular}{|c|c|c|c|c|c|c|c|c|c|}
\hline \multirow{2}{*}{2004} & \multicolumn{3}{|c|}{ Urban sample } & \multicolumn{3}{|c|}{ Rural stayers } & \multicolumn{3}{|c|}{ Movers into urban } \\
\hline & Obs & Mean & Std. Dev. & Obs & Mean & Std. Dev. & Obs & Mean & Std. Dev. \\
\hline Age & 3800 & 43.20 & 16.69 & 1843 & 41.99 & 13.55 & 75 & 40.17 & 13.64 \\
\hline Female & 3800 & 0.59 & 0.49 & 1843 & 0.62 & 0.49 & 75 & 0.56 & 0.50 \\
\hline Ukranian language & 3799 & 0.36 & 0.48 & 1843 & 0.69 & 0.46 & 75 & 0.13 & 0.34 \\
\hline Married & 3782 & 0.60 & 0.49 & 1836 & 0.72 & 0.45 & 74 & 0.73 & 0.45 \\
\hline Number of children & 3799 & 1.27 & 0.98 & 1842 & 1.67 & 1.09 & 75 & 1.28 & 0.97 \\
\hline Education level & 3797 & 2.72 & 1.02 & 1842 & 2.47 & 0.95 & 75 & 2.83 & 0.78 \\
\hline Employed & 3800 & 0.51 & 0.50 & 1843 & 0.49 & 0.50 & 75 & 0.60 & 0.49 \\
\hline Household income & 3639 & 866.30 & 741.70 & 1762 & 625.29 & 565.80 & 74 & 847.43 & 437.99 \\
\hline \multirow{2}{*}{2007} & \multicolumn{3}{|c|}{ Urban sample } & \multicolumn{3}{|c|}{ Rural stayers } & \multicolumn{3}{|c|}{ Movers into urban } \\
\hline & Obs & Mean & Std. Dev. & Obs & Mean & Std. Dev. & Obs & Mean & Std. Dev. \\
\hline Age & 3606 & 43.70 & 16.91 & 1851 & 44.71 & 13.87 & 49 & 40.20 & 13.94 \\
\hline Female & 3606 & 0.58 & 0.49 & 1851 & 0.62 & 0.49 & 49 & 0.49 & 0.51 \\
\hline Ukranian language & 3595 & 0.38 & 0.49 & 1840 & 0.67 & 0.47 & 49 & 0.35 & 0.48 \\
\hline Married & 3603 & 0.62 & 0.48 & 1850 & 0.73 & 0.44 & 49 & 0.69 & 0.47 \\
\hline Number of children & 3603 & 1.22 & 0.96 & 1850 & 1.70 & 1.06 & 49 & 1.53 & 1.12 \\
\hline Education level & 3585 & 2.98 & 0.82 & 1840 & 2.77 & 0.80 & 49 & 2.84 & 0.75 \\
\hline Employed & 3606 & 0.53 & 0.50 & 1851 & 0.51 & 0.50 & 49 & 0.69 & 0.47 \\
\hline Household income & 3438 & 2452.01 & 1717.34 & 1775 & 1829.06 & 1288.00 & 49 & 2082.53 & 1260.03 \\
\hline Risk indicator & 3533 & 0.26 & 0.44 & 1779 & 0.19 & 0.40 & 49 & 0.16 & 0.37 \\
\hline Risk index & 3533 & 3.77 & 2.90 & 1779 & 3.17 & 2.83 & 49 & 2.35 & 2.69 \\
\hline
\end{tabular}

Source: Autors' tabulations from the 2004 and 2007 waves of the ULMS. 
Table A.2 OLS estimation: Effects of the Big Five and risk on migration

\begin{tabular}{|c|c|c|c|c|c|c|c|c|c|}
\hline & $\begin{array}{c}(1) \\
\text { rural-urban }\end{array}$ & $\begin{array}{c}(2) \\
\text { rural-urban }\end{array}$ & $\begin{array}{c}(3) \\
\text { rural-urban }\end{array}$ & $\begin{array}{c}(4) \\
\text { rural-city }\end{array}$ & $\begin{array}{c}\text { (5) } \\
\text { rural-city }\end{array}$ & $\begin{array}{c}\text { (6) } \\
\text { rural-city }\end{array}$ & $\begin{array}{c}(7) \\
\text { rural-town }\end{array}$ & $\begin{array}{c}(8) \\
\text { rural-town }\end{array}$ & $\begin{array}{c}9) \\
\text { rural-town }\end{array}$ \\
\hline Age & $\begin{array}{c}-0.002^{* *} \\
(0.001)\end{array}$ & $\begin{array}{c}-0.002^{*} \\
(0.001)\end{array}$ & $\begin{array}{c}-0.002^{*} \\
(0.001)\end{array}$ & $\begin{array}{c}-0.002^{* * *} \\
(0.001)\end{array}$ & $\begin{array}{c}-0.002^{* * *} \\
(0.001)\end{array}$ & $\begin{array}{c}-0.002^{* * *} \\
(0.001)\end{array}$ & $\begin{array}{l}-0.000 \\
(0.001)\end{array}$ & $\begin{array}{c}0.000 \\
(0.001)\end{array}$ & $\begin{array}{c}0.000 \\
(0.001)\end{array}$ \\
\hline Age squared & $\begin{array}{c}0.001 \\
(0.001)\end{array}$ & $\begin{array}{c}0.001 \\
(0.001)\end{array}$ & $\begin{array}{c}0.001 \\
(0.001)\end{array}$ & $\begin{array}{c}0.002^{* *} \\
(0.001)\end{array}$ & $\begin{array}{c}0.002^{* *} \\
(0.001)\end{array}$ & $\begin{array}{c}0.002^{* *} \\
(0.001)\end{array}$ & $\begin{array}{l}-0.000 \\
(0.001)\end{array}$ & $\begin{array}{l}-0.001 \\
(0.001)\end{array}$ & $\begin{array}{l}-0.001 \\
(0.001)\end{array}$ \\
\hline Female & $\begin{array}{c}-0.008^{* *} \\
(0.004)\end{array}$ & $\begin{array}{c}0.003 \\
(0.005)\end{array}$ & $\begin{array}{c}0.002 \\
(0.005)\end{array}$ & $\begin{array}{c}-0.004 \\
(0.003)\end{array}$ & $\begin{array}{c}0.002 \\
(0.003)\end{array}$ & $\begin{array}{c}0.003 \\
(0.004)\end{array}$ & $\begin{array}{c}-0.005^{*} \\
(0.003)\end{array}$ & $\begin{array}{c}0.001 \\
(0.003)\end{array}$ & $\begin{array}{c}-0.000 \\
(0.003)\end{array}$ \\
\hline Ukrainian language & $\begin{array}{c}-0.046^{* * *} \\
(0.005)\end{array}$ & $\begin{array}{c}-0.049^{* * *} \\
(0.006)\end{array}$ & $\begin{array}{c}-0.048^{* * *} \\
(0.006)\end{array}$ & $\begin{array}{c}-0.016^{* * *} \\
(0.003)\end{array}$ & $\begin{array}{c}-0.018^{* * *} \\
(0.004)\end{array}$ & $\begin{array}{c}-0.018^{* * *} * \\
(0.004)\end{array}$ & $\begin{array}{c}-0.032^{* * *} \\
(0.004)\end{array}$ & $\begin{array}{c}-0.033^{* * *} \\
(0.004)\end{array}$ & $\begin{array}{c}-0.032^{* * *} \\
(0.004)\end{array}$ \\
\hline Risk indicator & $\begin{array}{l}-0.004 \\
(0.005)\end{array}$ & & $\begin{array}{c}-0.002 \\
(0.005)\end{array}$ & $\begin{array}{c}0.005^{* *} \\
(0.003)\end{array}$ & & $\begin{array}{c}0.007^{* *} \\
(0.004)\end{array}$ & $\begin{array}{c}-0.010^{* * *} \\
(0.003)\end{array}$ & & $\begin{array}{c}-0.009^{* * *} \\
(0.003)\end{array}$ \\
\hline Openness & & $\begin{array}{c}0.004^{* *} \\
(0.002)\end{array}$ & $\begin{array}{c}0.004^{* *} \\
(0.002)\end{array}$ & & $\begin{array}{c}0.002^{* *} \\
(0.002)\end{array}$ & $\begin{array}{c}0.002^{* *} \\
(0.002)\end{array}$ & & $\begin{array}{l}0.002^{*} \\
(0.001)\end{array}$ & $\begin{array}{l}0.002^{*} \\
(0.001)\end{array}$ \\
\hline Conscientiousness & & $\begin{array}{c}-0.011^{* * *} * \\
(0.003)\end{array}$ & $\begin{array}{c}-0.011^{* * *} \\
(0.003)\end{array}$ & & $\begin{array}{c}-0.008^{* * *} \\
(0.002)\end{array}$ & $\begin{array}{c}-0.008^{* * *} * \\
(0.002)\end{array}$ & & $\begin{array}{c}-0.004^{* * *} \\
(0.001)\end{array}$ & $\begin{array}{c}-0.004^{* * *} \\
(0.001)\end{array}$ \\
\hline Extraversion & & $\begin{array}{l}-0.003 \\
(0.002)\end{array}$ & $\begin{array}{c}-0.002 \\
(0.002)\end{array}$ & & $\begin{array}{c}-0.003^{* *} \\
(0.002)\end{array}$ & $\begin{array}{c}-0.004^{* *} \\
(0.002)\end{array}$ & & $\begin{array}{c}0.001 \\
(0.001)\end{array}$ & $\begin{array}{c}0.001 \\
(0.001)\end{array}$ \\
\hline Agreeableness & & $\begin{array}{c}-0.009 * * * \\
(0.003)\end{array}$ & $\begin{array}{c}-0.008^{* * *} \\
(0.003)\end{array}$ & & $\begin{array}{c}-0.004^{*} \\
(0.002)\end{array}$ & $\begin{array}{c}-0.004^{*} \\
(0.002)\end{array}$ & & $\begin{array}{c}-0.005^{* * *} \\
(0.002)\end{array}$ & $\begin{array}{c}-0.005^{* * *} \\
(0.002)\end{array}$ \\
\hline Neuroticism & & $\begin{array}{c}-0.005^{* *} \\
(0.002)\end{array}$ & $\begin{array}{c}-0.005^{* *} \\
(0.002)\end{array}$ & & $\begin{array}{c}-0.002 \\
(0.002)\end{array}$ & $\begin{array}{c}-0.002 \\
(0.002)\end{array}$ & & $\begin{array}{c}-0.004^{* *} \\
(0.002)\end{array}$ & $\begin{array}{c}-0.003^{* *} \\
(0.002)\end{array}$ \\
\hline Constant & $\begin{array}{c}0.112^{* * *} \\
(0.017)\end{array}$ & $\begin{array}{c}0.108^{* * *} \\
(0.020)\end{array}$ & $\begin{array}{c}0.109^{* * *} \\
(0.020)\end{array}$ & $\begin{array}{c}0.071^{* * *} \\
(0.013)\end{array}$ & $\begin{array}{c}0.078^{* * *} \\
(0.017)\end{array}$ & $\begin{array}{c}0.076^{* * *} \\
(0.017)\end{array}$ & $\begin{array}{c}0.044^{* * *} \\
(0.011)\end{array}$ & $\begin{array}{c}0.033^{* * *} * \\
(0.012)\end{array}$ & $\begin{array}{c}0.036^{* * *} \\
(0.012)\end{array}$ \\
\hline Observations & 7,656 & & & 7,548 & & & 7,547 & 6,066 & 6,027 \\
\hline Adjusted R-squared & 0.021 & 0.031 & 0.031 & 0.010 & 0.017 & 0.018 & 0.017 & 0.019 & 0.020 \\
\hline
\end{tabular}

Note: The table shows the OLS estimation results. The Big Five factors, risk measure and Set 1 controls are considered the same as those described in Table 4. Robust standard errors in parentheses; ${ }^{* *} \mathrm{p}<0.01,{ }^{* *} \mathrm{p}<0.05,{ }^{*} \mathrm{p}<0.1$. 


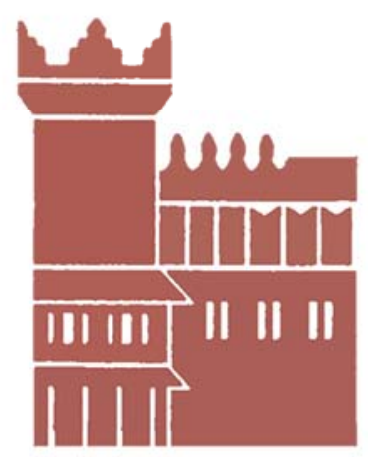

Alma Mater Studiorum - Università di Bologna DEPARTMENT OF ECONOMICS

Strada Maggiore 45

40125 Bologna - Italy

Tel. +39051 2092604

Fax +390512092664

http://www.dse.unibo.it 